\title{
Large extensional structures developed during emplacement of a crystalline thrust sheet: the Mondoñedo nappe (NW Spain)
}

\author{
José R. Martínez Catalán ${ }^{\mathrm{a}, *}$, Ricardo Arenas, ${ }^{\mathrm{b}, 1}$, María A. Díez Balda ${ }^{\mathrm{a}}$ \\ ${ }^{a}$ Departamento de Geología, Universidad de Salamanca, 37008 Salamanca, Spain \\ ${ }^{\mathrm{b}}$ Departamento de Petrología y Geoquímica, Universidad Complutense, 28040 Madrid, Spain
}

\begin{abstract}
The Mondoñedo nappe is a crystalline thrust sheet characterized by large recumbent folds, regional intermediate-pressure metamorphism, synkinematic intrusion of granitoids during nappe emplacement, and an extensional ductile shear zone developed within the nappe during thrusting. A large tectonic window permits the study of the footwall unit, revealing another extensional shear zone contemporaneous with thrusting and a low-pressure metamorphic evolution, in contrast to that of the hanging wall unit. The two main extensional shear zones produced $\mathrm{E}-\mathrm{W}$ extension parallel to the direction of orogenic shortening and normal to the orogenic structural trend. Furthermore, subordinate $\mathrm{N}-\mathrm{S}$ longitudinal extension was accommodated by normal faults in the footwall, and some of these faults were used as lateral ramps in late stages of thrusting.

The role of the extensional shear zones and faults described is discussed in the context of an evolving orogenic wedge dominated by plate convergence but characterized by large-scale rheological heterogeneities within it. Deep-seated viscous flow, triggered by heat accumulation, seems to account for the horizontal stretching and probable tapering of the orogenic wedge, which was induced by gravitational instabilities due to partial melting and underplating by buoyant continental crust.
\end{abstract}

Keywords: Crystalline nappe; Syn-orogenic extension; Orogenic wedge; Iberian Massif

\section{Introduction}

Studies of thrust sheets within the internal zones of orogenic belts are important in assessing crustal convergence, and estimating the long-term rheological behaviour of continental lithosphere. However, the emplacement history of crystalline thrust sheets is usually complex and difficult to ascertain, partly because they involve large portions of the crust (Hatcher and Hooper, 1992), and even the upper mantle, and include a wide range of rheological behaviours along a single allochthonous unit. Descriptions of large-scale thrust geometry and associated macrostructures less commonly focus on the internal zones of orogenic belts than in the external zones. Difficulties arise because crystalline thrust sheets involve rocks previously folded, so that the bedding cannot be taken as a horizontal reference

\footnotetext{
* Corresponding author. Tel.: +34-923-294488; fax: +34-923-294514.

E-mail addresses: jrmc@usal.es (J.R. Martínez Catalán)., arenas@geo. ucm.es (R. Arenas), mad@usal.es (M.A. Díez Balda).

${ }_{1}^{1}$ Tel.: + 34-91-3944908; fax: +34-91-5442535.
}

surface, in order to establish original fault dips or make estimates of displacement and shortening. Furthermore, many internal nappes are very large (larger than the largest foreland thrust sheet; Hatcher and Williams, 1986) and their outcrop is obscured by plutonic intrusions and late structures. Due to these problems, large associated structures are typically assumed to pre- or post-date thrusting, instead of investigating the possibilities of being coeval with it.

Structures whose kinematics do not fit the expected compressional dynamic framework, or omit parts of the normal stratigraphic sequence or metamorphic succession appear often associated to crystalline nappes. In some cases, they could be structurally induced by the geometry of the thrust fault (Dahlstrom, 1970; Coward, 1982; Wibberley, 1997), linked to the development of imbricates, out-ofsequence thrusts or tear faults (Butler, 1982; Morley, 1988; Mueller and Talling, 1997), or be equivalents to Riedel shears oblique to the basal thrust (Yin and Kelty, 1991). But, in other cases, their size, in relation to the nappe to which 
they are associated, and their imprint in its metamorphic evelution pøint to large-scale phenomena, related the dynamics of the whole orogenic belt rather than the individual alløchthønous units.

In particular, extensional structures have been found in a number of large crystalline thrust sheets in the Scandinavian Caledonides (Fossen, 1992, 2000; Milnes et al., 1997), the European Variscides (Burg et al., 1994; Pitra et al., 1994), the North American Cordillera (Hødges and Walker, 1992) and the Himalayas (Burg et al., 1984; Hodges et al., 1996), among others orogenic belts. There, much attention has been paid to the syn- or postorogenic character of the extensional structures. Før instance, Fossen (2000) pøinted -ut that whereas in the Caledonides, extension is essentially

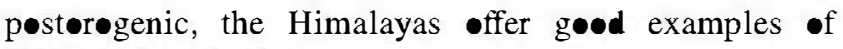
synorøgenic extension.

The problem with synorøenic extension is how a løcal stress field can develop opposite to the regional or distant convergence-related stress field. Commonly invoked explanations are the upwelling of some hot and buøyant material, such as the asthenosphere or mølten crust and mantle rocks (Van Den Driesche and Brun, 1991-1992; Vanderhaeghe et al., 1999), and the creation of a high top graphic relief, which may develop vertical stresses high enøugh to make unstable and collapse a large portion of the mountain belt (England, 1983; Burg et al., 1984; Burchfiel and Røyden, 1985; Dewey, 1988; Mølnar and Lyon-Caen, 1988). In the latter case, the relief may simply result from crustal or lithospheric thickening due to convergence, or be a consequence of the removal of the mantle lithospheric root either by detachment or by convective erosion (Platt and Vissers, 1989; Platt, 1993).

Much of the discussion on synor genic extension in mountain belts is linked to that of exhumation of deepseated structural units, often shøwing evidence of highpressure metamorphism. The quick exhumation rates required for the preservation of high-pressure parageneses is difficult to explain by erøsion $\bullet$ ly, and has been linked to tectonic denudation in many cases (Davies and Warren,

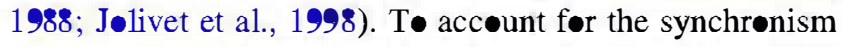
-ften observed between exhumation and convergence, Platt (1986) discussed the mechanics of or genic wedges consisting of viscous material, typical of the internal zones of or genic belts. Althøugh inspired in the wellestablished mechanics of accretionary wedges with Coulømb behaviøur (Davis et al., 1983; Dahlen et al., 1984), he

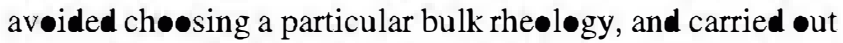
a merely qualitative analysis. From it, he suggested that

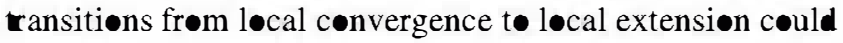
be driven by changes in wedge geometry, and showed how extension may occur in parts of the wedge during continuous convergence.

Platt's conclusions pertaining to tectonic denudation do not differ essentially from the models relating extension with gravitational collapse, but provide mechanisms by which the wedge can be thickened and turned unstable, namely changes in its internal rhe logy or in the rate of convergence, and underplating by continental slices. Obviøusly, the generation of mølten, buøyant material represents a drastic rhe logical change inside the wedge (which may modify the local stress field), and the addition - f mantle material may be a kind of magmatic underplating.

The idea that adjustments inside the orogen, including extensional structures, is related to viscous flow in its deep parts, is gaining adepts progressively. Althøugh primarily seen as a post-convergence phenømenon (Sandiford, 1989; Block and Royden, 1990; Van Den Driesche and Brun, 1991-1992; Costa and Rey, 1995), it can overlap with -rogenic shortening if convergence continues after the middle and/or løwer crust have had enough time to develop a løw-viscosity hot layer (Clark and Royden, 2000; Beaumont et al., 2001; Shen et al., 2001).

The aim of this article is te demonstrate that large extensional structures in the Mondoñedo nappe and its aut and, mostly, during the emplacement of the nappe itself. Extension was mainly ransversal to the structural trend; that is, it took place in the direction of nappe emplacement-

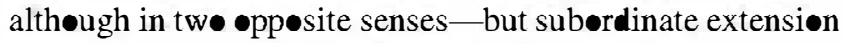
-ccurred alsø longitudinally. Extensional and compressive structures interfered during nappe emplacement, and crosscutting structural criteria, together with overprinting metamorphic relationships, information extracted frøm synkinematic granit $\bullet$ ids, and published age data, permit a detailed reconstruction of the evolution of this area of the Iberian Massif. The deduced tectonothermal history is then discussed in the context of the Variscan orøenic wedge and its kinematics, which includes the role of viscous flow ass ciated with high-grade metamorphic rocks develøped below the nappe.

\section{Setting and previous work}

The Mondoñedo nappe is a large crystalline thrust sheet -ccurring in the internal zones of the NW Iberian Massif, and made up of low to high-grade metasediments and several massifs of synkinematic granit॰ids (Figs. 1 and 2). It was first described by Matte (1968) as a large recumbent anticline, and then by Marces (1973), whe mapped its frontal thrust and stated its importance as a first-order allochthonous unit of the Variscan internal zones. The southern branch of the nappe was mapped by Pérez-Estaún (1978), and further research along the coastal section showed the existence of a 3-3.5-km-thick basal ductile shear zone (Figs. 3 and 4) in its internal parts (Bastida and Pulgar, 1978). Martínez Catalán (1980) identified the basal thrust outcropping in these internal parts and mapped the thrust and associated shear zone, showing the existence of two tectonic windows, named Xistral and Monte Carballesa (Fig. 1). The thrust front can be traced for $200 \mathrm{~km}$ and a 


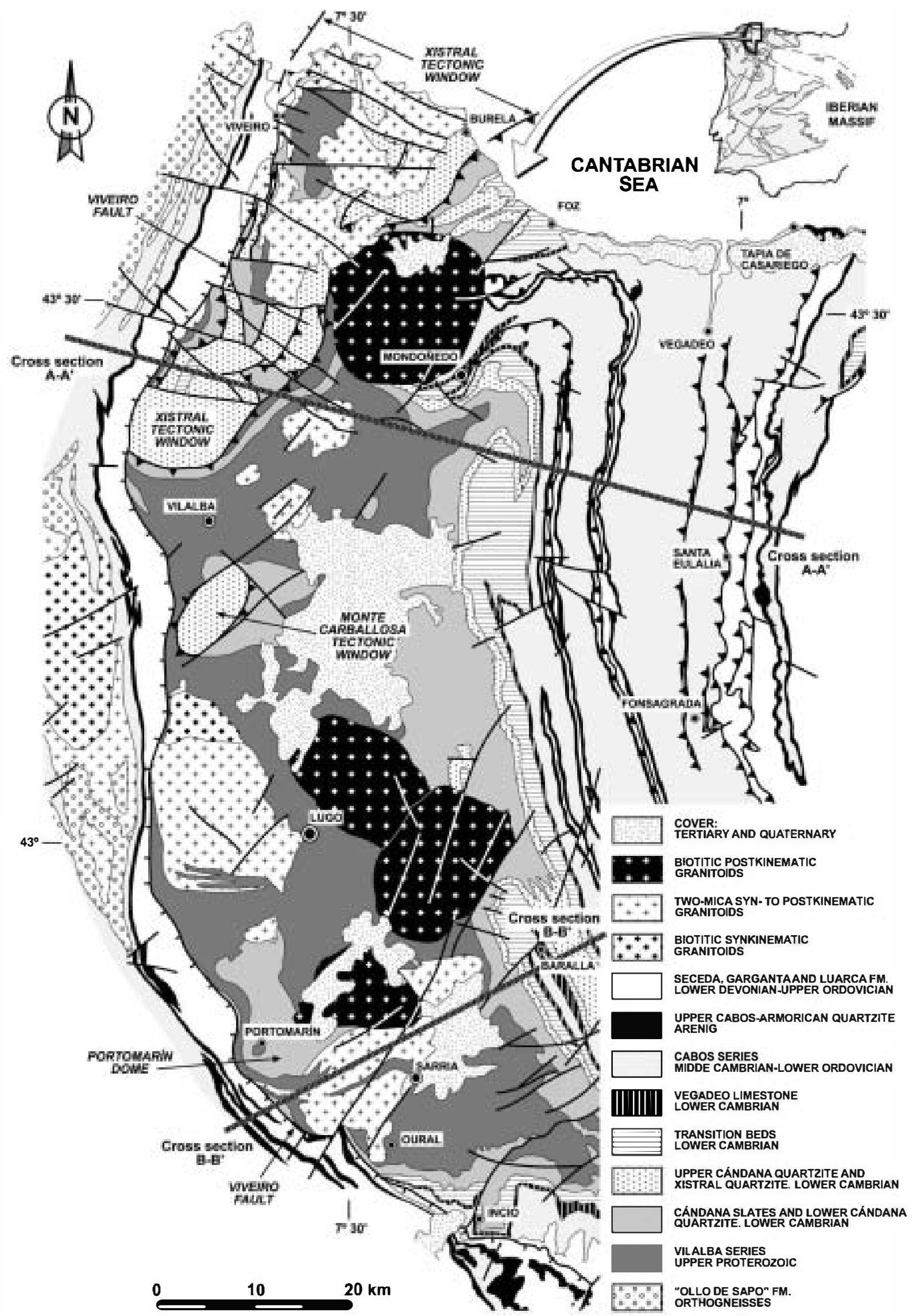

Fig. 1. Geological map of the northern and central parts of the Mondonedo nappe. 


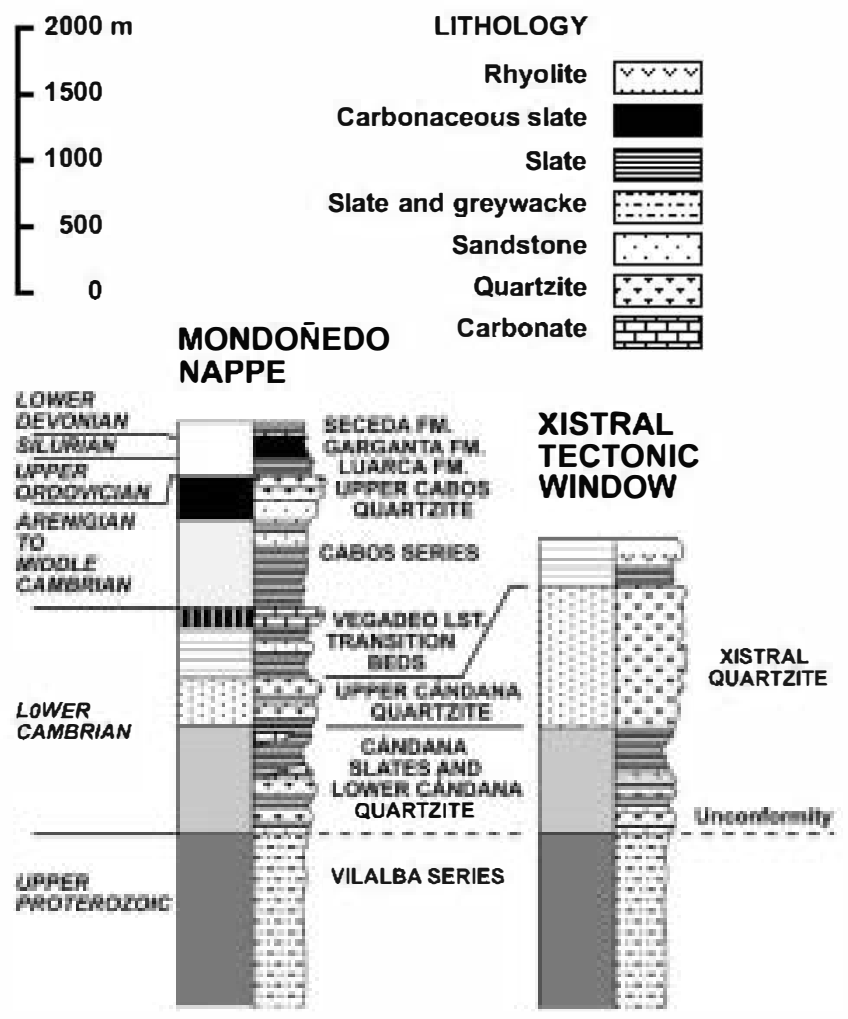

Fig. 2. Swatigraphy of the Mondonedo nappe and its autochthon (Xiswal tectonic window). The key to the swatigraphic divisions (left hand columns) is given in Fig. 1.

width of $65 \mathrm{~km}$ is measurable for the thrust sheet between its frontal thrust and the western limit of the tectonic windows. Displacement cannot be measured because of the absence of correlatable cut- $\bullet$ ffs between the hanging wall and the footwall. However, correlation between two Lower Cambrian quartzite formations (Upper Cándana and Xistral quartzites; Fig. 2), permits a minimum estimate of $45 \mathrm{~km}$ (see cross-section $\mathrm{A}-\mathrm{A}^{\prime}$ in Fig. 4).

The nappe consists of $3000 \mathrm{~m}$ of Upper Prøterøaic slates and greywackes, the Vilalba Series, and another $3000 \mathrm{~m}$ of Lower to Middle Paleøuic clastics and carbonates of shalløw-water platform facies, løcally reaching the Lower Devonian (Fig. 2). Slates are the most common lithøløgies, følløwed by quartzites. The Paleoz⿺ic is thicker in the footwall unit (7000-10000 m), but appears incomplete in the tectonic windows. A strongly competent horizon of Lower Cambrian sandstones, the Xistral Quartzite, occupies most of the windows, reaching a structural thickness of $5000 \mathrm{~m}$ after having been folded and locally repeated by thrusting.

The sedimentary succession was deformed during the Variscan orogeny. A first deformation episode of eastverging recumbent folding was followed by ductile and brittle thrusting toward the east (Figs. 3 and 4). Subsequent open steep folding allowed the present-day preservation from erøsion of arøund $10 \mathrm{~km}$ of the Mondeñedo thrust sheet in an $\bullet$ pen synform. The basal parts of the thrust sheet øutcrøp at its frønt and als surrounding the tectonic windows. To the west, the thrust sheet is bounded by the Viveirø fault, a west-dipping normal fault cutting acrøss the nappe and its autochthon (Figs. 1, 3 and 4).

Detailed structural analyses of the hanging wall unit and the basal ductile shear zone can be found in Martínez Catalán (1985), Bastida et al. (1986) and Aller and Bastida (1993). These contributions deal with the geometry of the

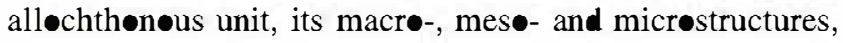
the synkinematic metamorphism, and the geomery and kinematics of the basal shear zone. The significance of the Møndoñedo nappe in the structural evelution of the Variscan belt of NW Spain is discussed in Pérez-Estaún et al. (1991).

In previous works, the only contractional ductile shear zone identified was at the base of the hanging wall unit (the Mondeñedo nappe itself), the only extensional structure identified was the post-nappe Viveir fault, and the structure -f the tectonic windows was poorly known. Nappe emplacement was simply viewed as an allochthonous sheet moving withøut much internal deformation over the basal ductile shear zone and sliding along a brittle thrust fault once relatively high crustal levels were reached. Contemporaneous erosional denudation was assumed to account for decompression indicated by the metamorphic evolution, and extensional deformation was considered to have $\bullet$ curred essentially in a pøst-nappe stage (Martínez Catalán, 1985).

After a careful review of the hanging wall unit, new mapping of the footwall unit in the tectonic windows, and a petroløgical study of the metamorphic ev lution, a complex picture of ductile shear zones (Figs. 3 and 4), with different kinematics and partially overlapping in time, has emerged. The peroløical study has been carried out in representative domains of the nappe and its footwall unit, but these results are presented in a companion paper (Arenas and Martínez Catalán, 2003).

\section{Shear zones in the hanging wall unit}

The structure of the Mondoñedo nappe is dominated by east-verging recumbent følds. The geømetry of these large folds suggest a strong flattening, which is corroborated by a pervasive axial planar cleavage $\left(S_{1}\right)$. The $\bullet$ verturned limb of the main recumbent føld, the Mondoñed-Lug•-Sarria (MLS) anticline, reaches $15 \mathrm{~km}$ in the upper parts of the stratigraphic section (Fig. 4). The recumbent folds reflect an episode of crustal shortening and thickening, and were affected by a regional metamorphism of intermediate pressure, as defined by Miyashir (1961), with kyanitesillimanite, common in midcrustal levels of many orøenic belts (Thompson and England, 1984). The metamorphic zœning, of Barrøvian type, includes chlørite, biøtite, gamet, staur-lite-kyanite, sillimanite and sillimanite-orthøclase 


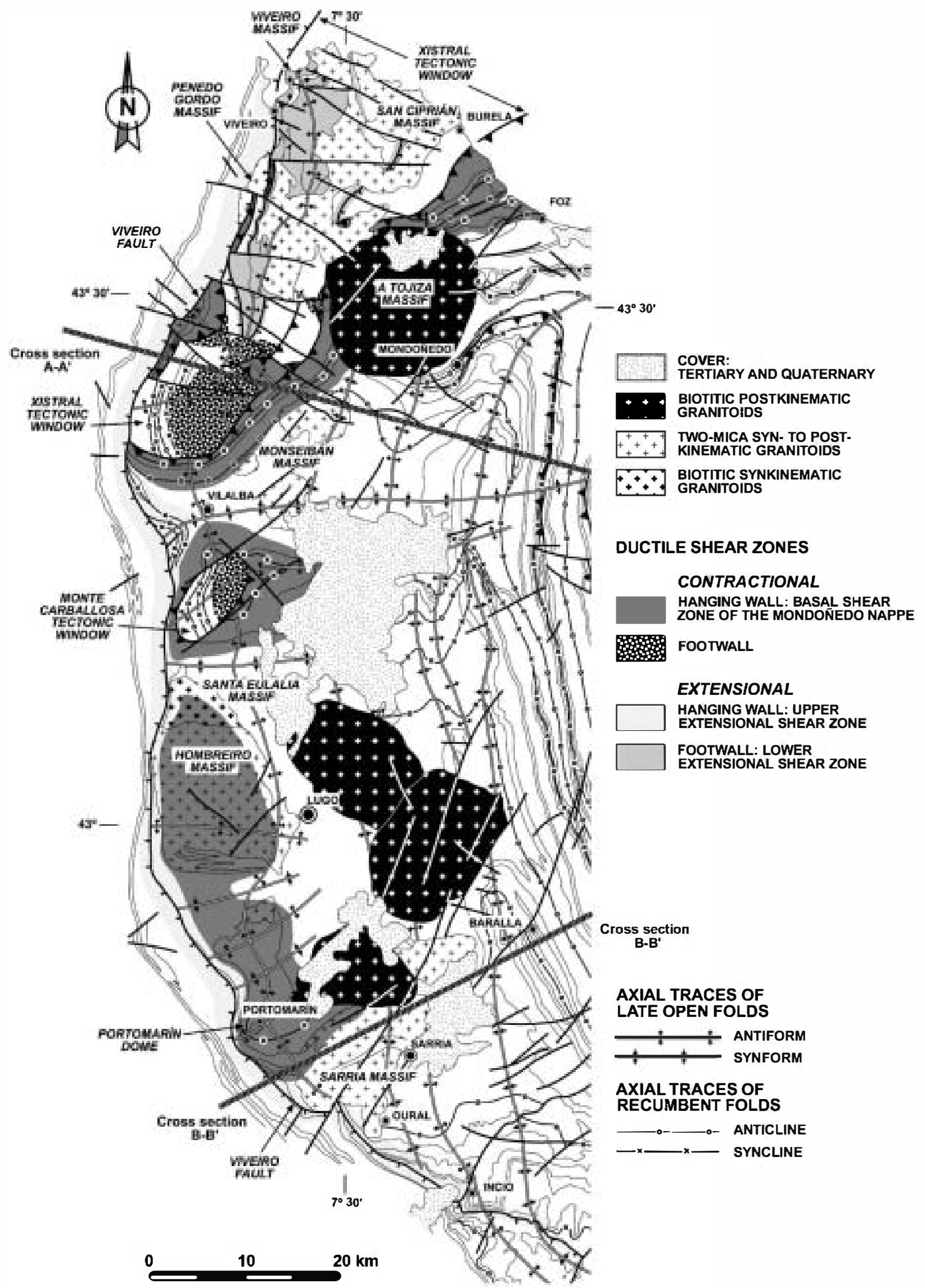

Fig. 3. Map showing the dis wibution of ductile shear zones in the hanging wall and footwall to the Mondonedo thrust and the axial traces of major folds. Faults and unit boundaries allow a comparison with Fig. 1. Swatigraphic and lithological keys are used only for cover and granite massifs. 

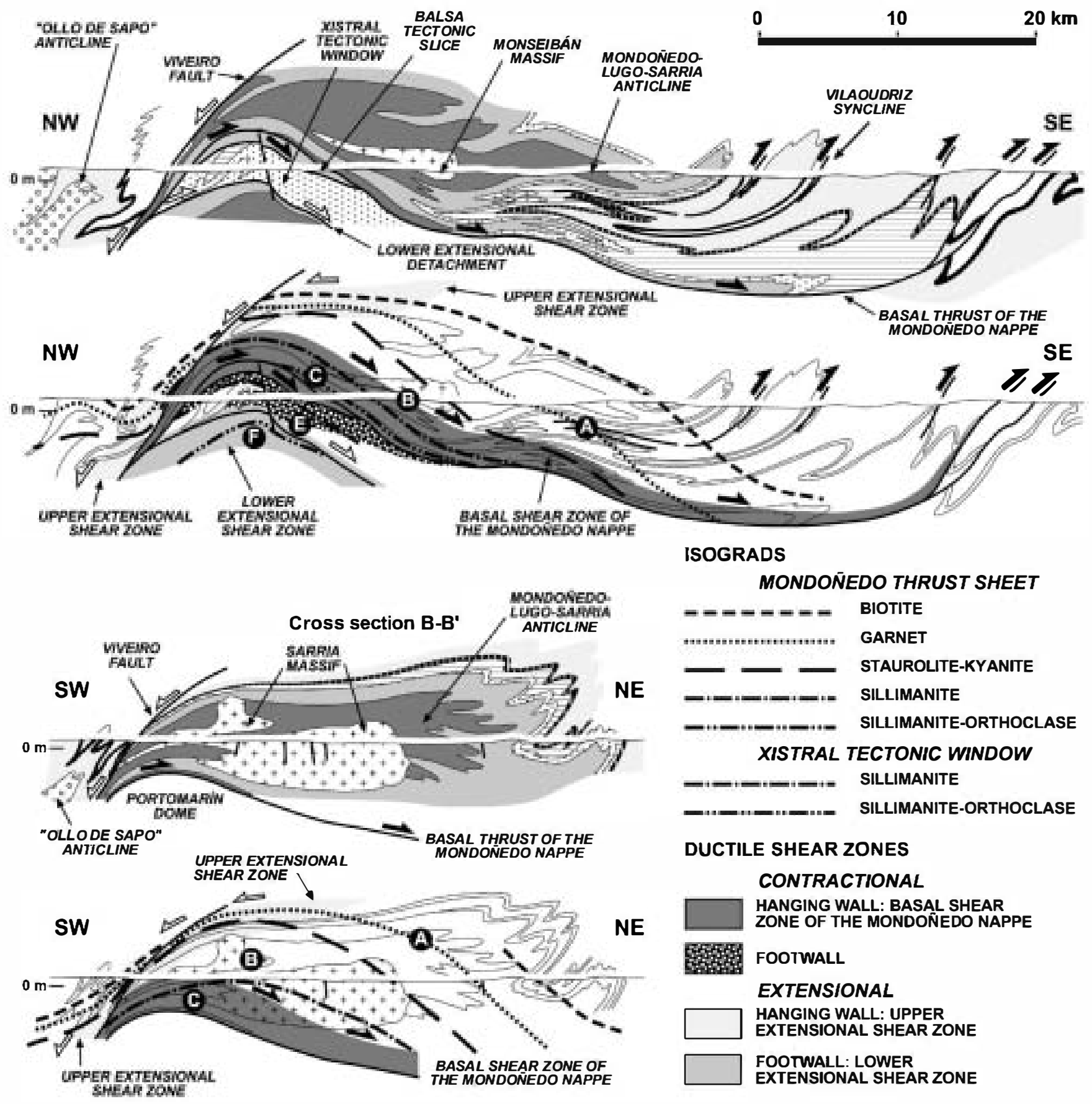

Fig. 4. Two general sections across the Mondonedo nappe, each shown in two versions. The first depicts the lithoswatigraphic units (see legend in Fig. 1), and the second, the shear zones and the metamorphic isograds. Arrows show movement of conractional (black) and extensional (white) shear zones and faults. For location, see Figs. 1 and 3. Letters A-F refer to the location of the P-T paths shown in Fig. 6.

(Fig. 5). The is grads crosscut the recumbent følds (Capdevila, 1969), and were deformed by the subsequent ductile shear zones and cut by the thrust and normal faults (Fig. 4).

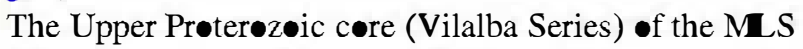
anticline has a mean thickness of $6 \mathrm{~km}$ aløng møst of the føld, as deduced from cross-sections constructed by downplunge projection $\bullet$ the hinges and limbs of the second-

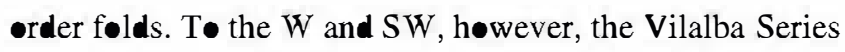
becomes progressively thinner, and the fold core is less than $1 \mathrm{~km}$ thick (Fig. 4). The thinning of the fold nappe toward its internal parts is not only reflected in the core of the anticline, but als in the thickness of the Paleøzic formations on both limbs and in the width of the metamorphic zones (Figs. 4 and 5). Thinning is due to the superposition of tw ductile shear zones with opposite senses of movement. One of these 


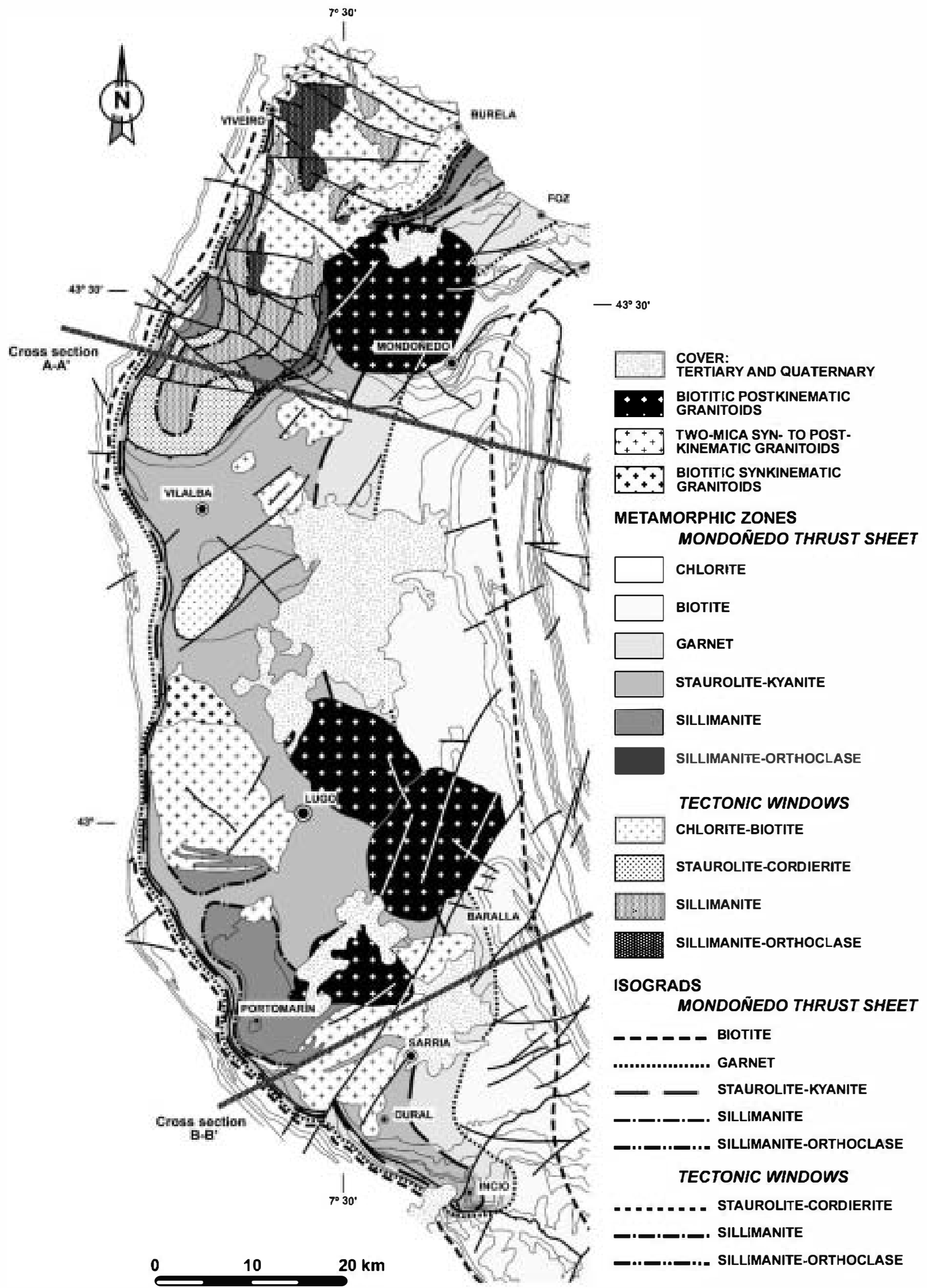

Fig. 5. Map of metamorphic zones and isograds. Note how the zones narrow in the western part of the nappe, due to the superposition of the upper extensional shear zone and the Viveiro fault. 


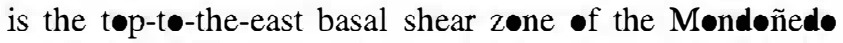
nappe, which sheared and thinned the overturned limb of the MLS anticline, doubling its cross-sectional length in its deep parts, where it attains more than $30 \mathrm{~km}$ (compare units deformed in the shear zone with units in less deformed parts abøve in cross-section $\mathrm{A}-\mathrm{A}^{\prime}$-f Fig. 4). The other shear zone is a shallow-dipping extensional ductile structure with topto-the-west motion, developed in the upper parts of the MLS anticline (Fig. 4; cross-sections $\mathrm{A}-\mathrm{A}^{\prime}$ and $\mathrm{B}-\mathrm{B}^{\prime}$ ).

This section describes both the basal (reverse) and the upper (normal) shear zones, and demonstrates their temporal øverlapping. The tecton॰thermal evølution of the nappe will be outlined along with the structural description. A detailed petrological description of the metamørphism is provided elsewhere (Arenas and Martínez Catalán, 2003). Here, only the key aspects emerging from our study of the regional and local distribution of metamorphic zones (Fig. 5), and the $\mathrm{P}-\mathrm{T}$ conditions and evelution will be mentioned. Three $\mathrm{P}-\mathrm{T}$ rajectories corresponding to upper, intermediate and lower parts of the Mondoñedo thrust sheet are shown in Fig. 6, paths A, B and C, respectively. Little control is available for the prograde paths (dashed), but the pressure peaks vary frøm 6 t• $11-12 \mathrm{kbar}$, indicating that the pile of recumbent følds reached a depth of $38-45 \mathrm{~km}$, and what

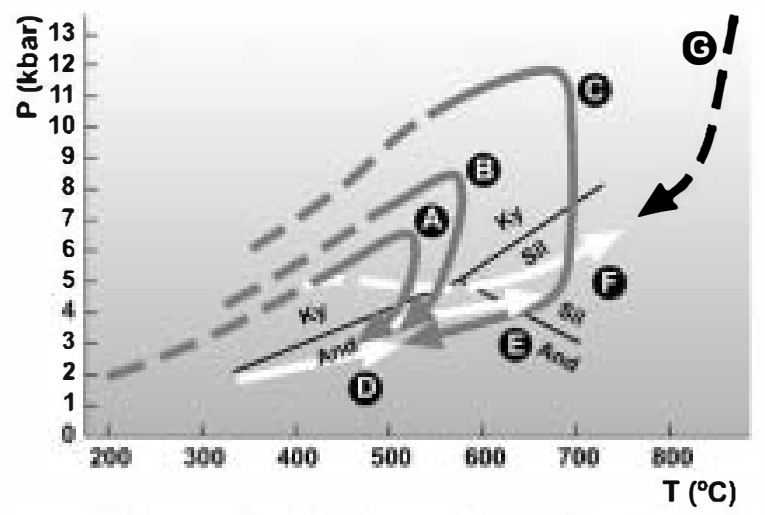

GENERAL P.T PATHS FOR THE MONDOÑEDO NAPPE

A Upper part of the nappe. Biotite and garnet zones

B Middle part of the nappe. Staurolite-kyanite zone

C Lower part of the nappe. Sillimanite and sillimanite-orthoclase zones

GENERAL P-T PATHS FOR THE FOOTWALL UNIT OF THE MONDOÑEDO NAPPE

D Hanging wall to the lower detachment. Chloritebiotite zone

E Hanging wall to the lower detachment. Staurolite-cordierite and sillimanite zones

F Footwall to the lower detachment Sillimanite and sillimanite-orthoclase zones

(G) Deep, ascending thermal source

Fig. 6. P-T paths for the Mondoñedo thrust sheet (grey arrows), its footwall unit (white arrows), and deeper crustal rocks underlying the lower extensional shear zone (black arrow). The paths are representative of different parts of the nappe and its autochthon, which are indicated with capitals in the cross-sectons of Figs. 4, 8 and 13. Based on Arenas and Martínez Catalán (2003). Dashe lines represent parts of the paths not based on petrological data. presently constitutes the nappe was initially around $20 \mathrm{~km}$ thick. Temperature peaks are close to pressure peaks and vary from 500 te $700^{\circ} \mathrm{C}$.

\subsection{Basal shear zone of the Mondoñedo nappe}

The basal shear zone is narrow at the frontal parts of the

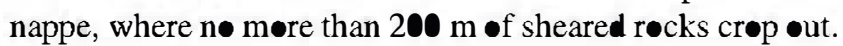
The shearing $\bullet$ verprints earlier structures and developed a crenulation fabric in slates, very low-grade phyllonites and cataclasites (Marcos, 1973). Conversely, the thickness of the basal ductile shear zone attains $3-3.5 \mathrm{~km}$ in the internal parts of the nappe, where it crøps out surrøunding the tw॰ tectonic windows and alse in two domes formed by interference of orthøgonal late open følds in Portomarín and to the west of Lug• (Figs. 3 and 4). The shear zone is characterized by a generalized crenulation cleavage or a new medium-grained schistosity $\left(S_{2}\right)$ in the pelites, a mylonitic foliation in the quartzites (Bastida and Pulgar, 1978), and a mineral lineation roughly striking E-W. Minor følds with curved hinges, including sheath folds, and S-C structures are als common. The kinematic indicators consistently give a top-to-the-east sense of shear. A few metres of ultramylonites have been found locally at the thrust surface.

Aller and Bastida (1993) described in detail the basal shear zone along the coast, to the east of the Xistral tectonic

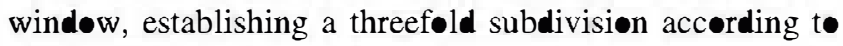
microstructural criteria. In the lower levels, mylonites and ultramylonites are common, and quart $z$ c-axis fabrics are of the small-circle type (Schmid and Casey, 1986). This indicates strong shearing at low temperature conditions, and represent late stages of thrusting, contemporaneous with greenschist facies retrogradation. The middle part of the shear zone contains blastomylonites, and the quart $z$-axis fabrics are of the monoclinic incomplete single girdle and type I crossed girdle, suggesting deformation at higher metamorphic conditions, mostly in the amphibølite facies. The upper part includes non-mylonitic quartzites and quartzites with small-circle type and type I crossed girdle which, together, suggest lower temperatures than in the central parts.

The internal parts of the basal zone suffered the highest $\mathrm{P}-\mathrm{T}$ conditions, and als the most intense retrogradation. After the Barrovian-type metamorphic event, nappe emplacement began along the ductile shear zone. Sillimanite grew synkinematically in the deeper parts of the nappe, while andalusite porphyroblasts developed in its upper parts. All the $\mathrm{P}-\mathrm{T}$ paths show a decompression, which was greater in the deeper parts (compare paths $\mathrm{A}$ and $\mathrm{B}$ with path $\mathrm{C}$ in Fig. 6 and their locations in Fig. 4). The decompressive paths were, at an initial stage, close to is thermal for the lower parts (Fig. 6, path C), suggesting a quick exhumation (Thompson and England, 1984), a feature commonly associated with tectonic denudation. Conversely, the late stage shows cooling accompanied with slight decompres- 
sion. This corresponds to a relatively thin thrust sheet (roughly $12 \mathrm{~km}$, indicated by the $3 \mathrm{kbar}$ at its base; see path $C$ in Fig. 6) being emplaced at relatively shallow levels and undergøing only slight denudation.

The presence of deformed Variscan granit॰ids is another important feature of the basal shear zone. The Sarria, Hømbreirø, Santa Eulalia, Mønseibán (Fig. 3) and øther minor massifs partly intruded int the shear zone, and were sheared toward the east (Fig. 4). Martínez Catalán (1983) and Aranguren and Tubía (1992), described the microstructures and estimated the temperature conditions of deformation, which were cløse to the sølidus temperature for granite. The fact that shearing closely followed their emplacement pøints to their synkinematic character.

\subsection{Upper extensional shear zone}

In the western region of the nappe, the stratigraphic sequence, the recumbent folds and the metamorphic zones thin gradually the west (Figs. 4 and 5). This is a region where a subhorizontal crenulation cleavage or a new schistosity was developed, as well as an E-W mineral lineation. This region contrasts with wide areas to the east, which are structurally lower, and where only the first cleavage $\left(S_{1}\right)$ is present. There is clearly a zone of deformation superimposed on the normal limb of the MLS anticline. Its maximum thickness is estimated at $2 \mathrm{~km}$, and decreases progressively to the south of Oural (Fig. 3). Asymmetric pressure shadows, developed around pre- and synkinematic porphyroblasts, indicate a top-to-the-west sense of shear.

The shear zone deforms the recumbent folds and the Barrovian metamorphic zones, and is considered to postdate them. Høwever, pørphyroblasts of kyanite, staur lite and andalusite grew in the shear zone synkinematically with the second cleavage. This implies that the $\mathrm{P}-\mathrm{T}$ conditions were still high, and suggests that motion in the shear zone began during the early stages of nappe emplacement. Because the $\mathrm{P}-\mathrm{T}$ conditions were greater there than at the base of the thrust sheet in later stages of emplacement, the upper shear zone probably finished its activity before the end of the thrusting process.

An additional criterion for the relatively early timing of the upper shear zone is provided by the Sarria massif: its upper part intruded the shear zone after shearing had ceased, because the granite is undeformed there. However, the massif intruded in the nappe while it was still being emplaced, and was deformed within the basal shear zone (Figs. 3 and 4).

The thinning of the metamorphic zones and the apparently down-dip motion (top-t॰-the-west) suggest a normal character for the shear zone, being equivalent to a brøad extensional detachment. In terms of thermøbarometry, this is reflected in the is thermal, decompressive portion of the $\mathrm{P}-\mathrm{T}$ paths followed by the deep parts of the Mondøñedø nappe (Fig. 6, path C). Its kinematics might imply the tectonic extrusion of the MLS anticline from the root zone, in a way comparable with that proposed by Dietrich and Casey (1989) for the Helvetic nappes. However, the MLS anticline is different to the Helvetic case, as the upper shear zone has a sense of motion $\bullet p-s i t e$ to that of the basal one. Alternatively, the upper extensional shear zone may be a consequence of gravitational cøllapse, in response to gravitational gradients created by orogenic topography.

The upper shear zone was later overprinted by the Viveir normal fault. Because of the spatial coincidence of both structures (Fig. 3), they have been considered assøciated (Martínez Catalán, 1985; Martínez et al., 1996). However, in the light of the new data, they are considered here to be separated in time: the upper ductile shear zone moved during nappe emplacement, whereas the Viveirø fault cuts the Mondeñedø thrust sheet and its autechthon.

\section{Shear zones in the footwall unit}

In the western part of the Mondoñedo nappe, two

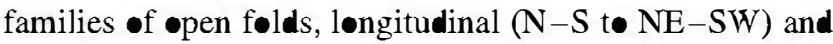
transverse (NW-SE to E-W), interfere allowing the føotwall unit to crøp out (Fig. 3). A løngitudinal antiførm is essentially responsible for the large northern tectonic window (Xistral), and the same, when interfering with an $\mathrm{E}-\mathrm{W}$ transverse antiform, causes the southern small window (Monte Carballosa). This section describes the different structural units exposed in these tectonic windows, together with the main ductile shear zones identified (Fig. 7). Focusing on the Xistral window (except when specifically stated), this section uses longitudinal and transverse cross-sections (Fig. 8) to study the complex pattern of compressional and extensional structures contemporaneous with thrusting. A three-dimensional sketch showing the relationships between the main compressional and extensional structures is shown in Fig. 9.

The Xistral Quartzite (Fig. 2) was strongly følded priør t• nappe emplacement. When not affected by additional deformation, cross-bedding indicates the way-up direction, permitting the mapping out the large følds. In these cases, the $S_{1}$ f liation is axial planar to the følds, a stretching lineation is not thoroughly developed and textures are not mylonitic. Conversely, when affected by subsequent shear zones, the quartzites were mylonitized, a pervasive elongation of quartz grains developed, commonly striking E-W (Fig. 7), and cross-bedding is poorly preserved and difficult tø interpret. In addition, new minør følds develøped locally.

Relics of the basal shear zone of the Møndoñedo nappe have been preserved in the footwall unit, and several tectonic slices exist close the thrust fault. Furthermore, a strain gradient to the SE is identified in the Xistral Quartzite in the south, and interpreted as a contractional shear zone converging upward int the Mondeñed॰ basal thrust. 


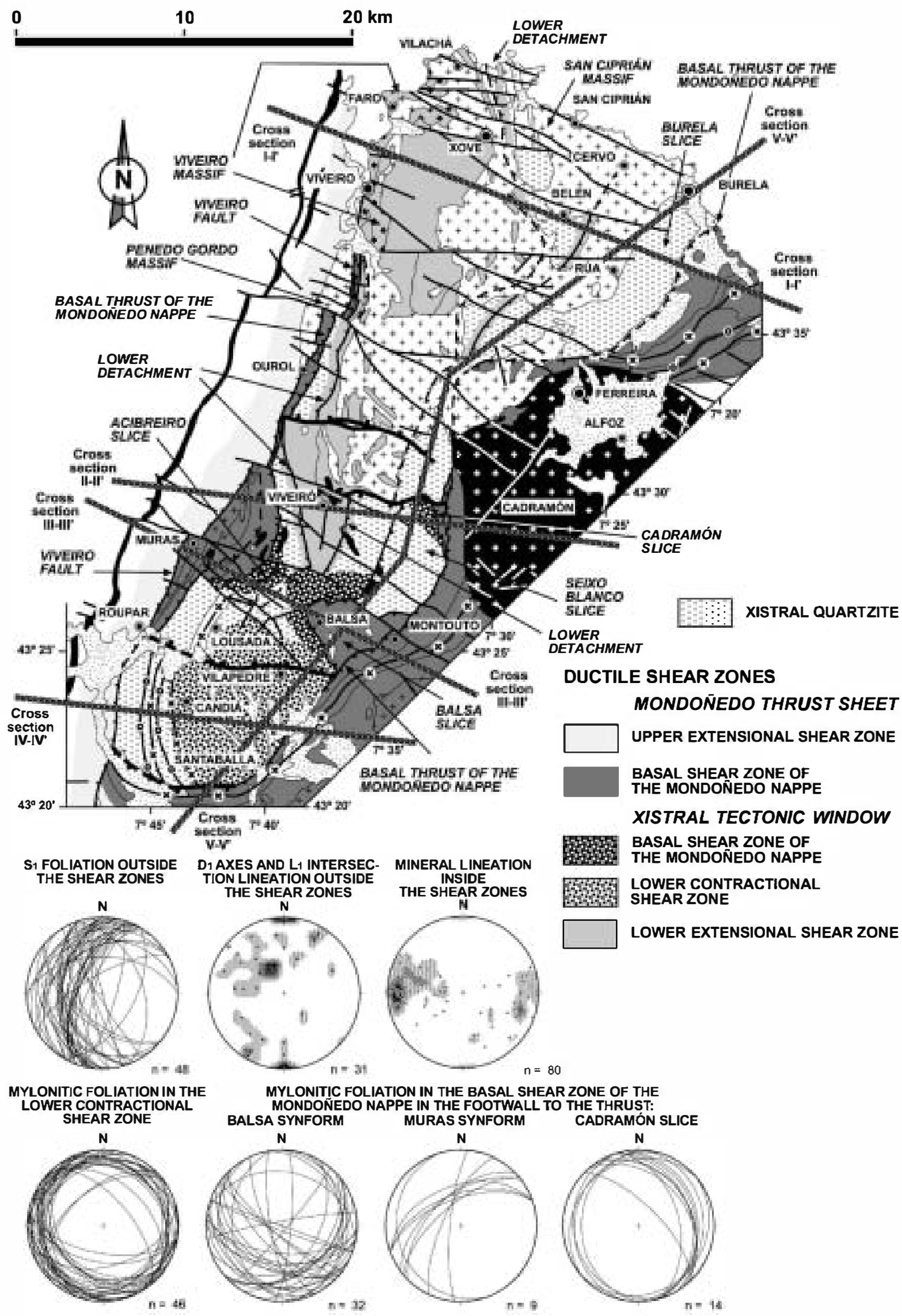

Fig. 7. Map showing the dis wibution of ducte shear zones in the Xis tectonic window, and diagrams depicting the atritude of foliation and lineation (lower hemisphere, equal area stereographic projection). 


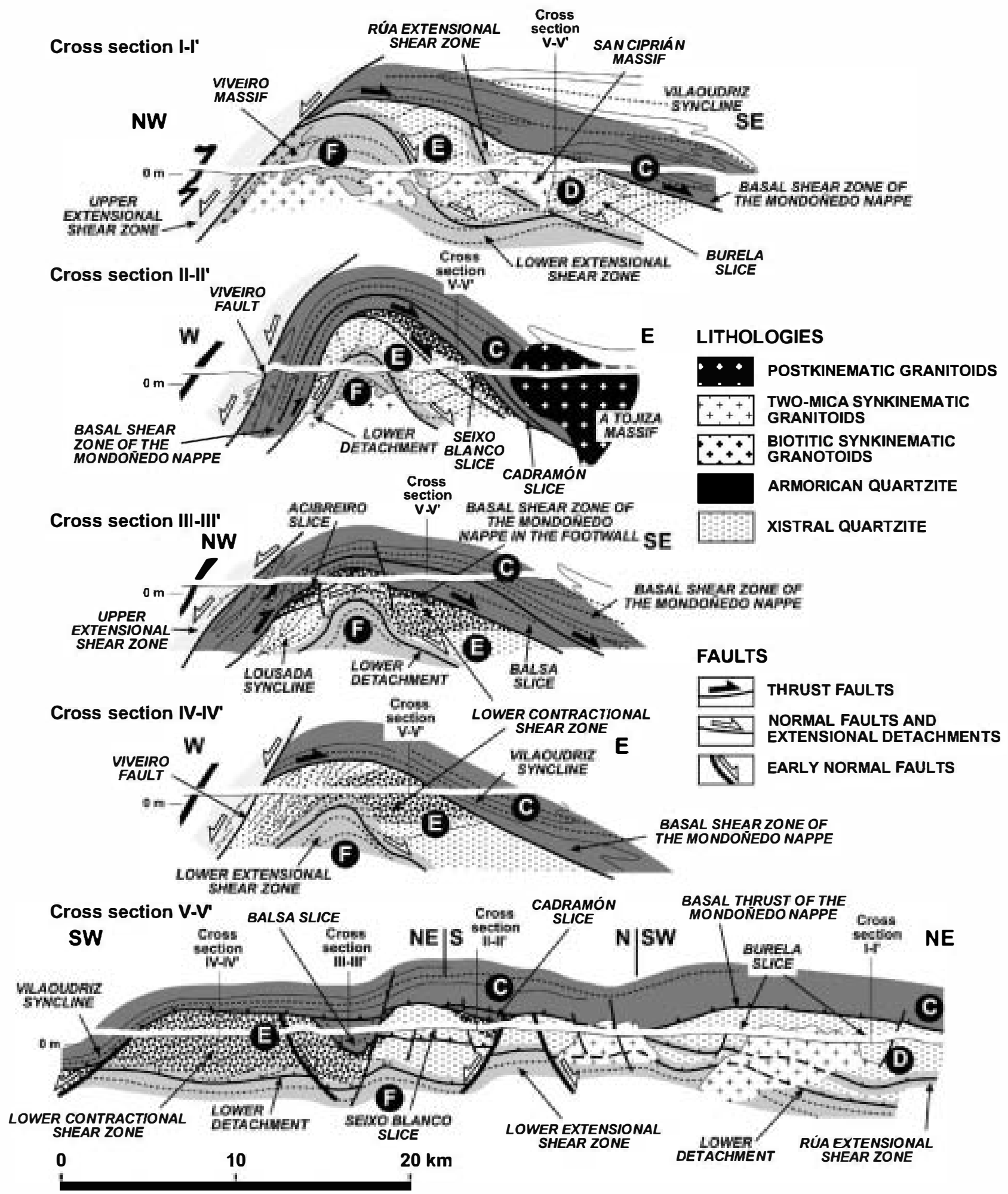

Fig. 8. Geological sections across the Xiswal tectonic window showing the ducte shear zones and faults. For location, see Fig. 7. For legend of the shear zones, see Figs. 3 and 4. Letters $\mathrm{C}-\mathrm{F}$ refer to the location of the $\mathbf{P}-\mathrm{T}$ paths depicted in Fig. 6 . Thin dashed lines show the at outude of the main foliation: $S_{1}$ outside the shear zones, and $\left(S_{1}+\right) S_{2}$ in the shear zones.

The main extensional structure is a detachment situated at the bottom of the quartzitic formation and below it (Figs. 7-10). In addition, horizontal extension affected the quartzite in both longitudinal and transverse directions.
The E-W extension created faulted blocks that underwent domino-style rotation (Fig. 8, cross-section $\mathrm{I}-\mathrm{I}^{\prime}$ ). The $\mathrm{N}-\mathrm{S}$ extension gave rise to transverse normal faults cutting across the footwall unit (Fig. 8, cross-section $\mathbf{V}-\mathbf{V}^{\prime}$, and 


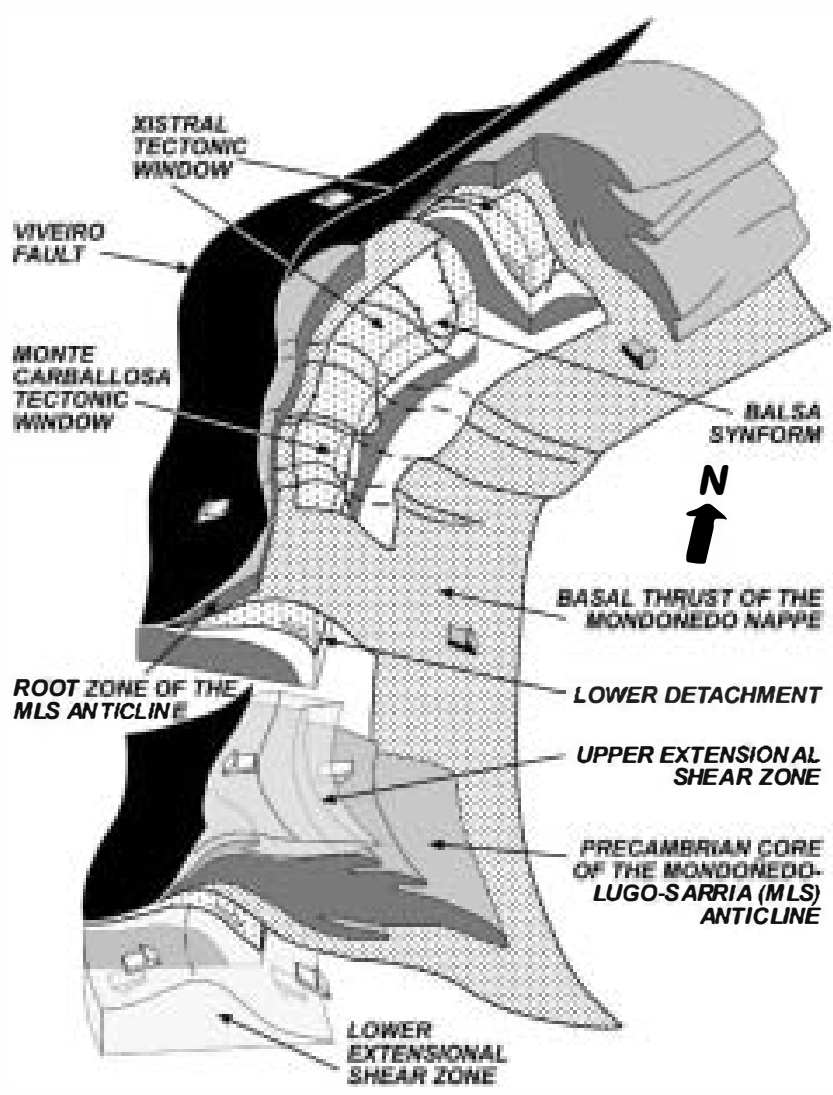

Fig. 9. Three-dimensional sketch showing the relationships between the main contractional and extensional suctures. The upper part of the figure depicts the crosscutting relationships between folds and faults, whereas the lower block shows the two main extensional ductile shear zones (light grey, 'wansparent'). The contractional ductile shear zones are not shown.

Fig. 9). All these structures were active during different stages of nappe emplacement.

The metamorphic ev॰lution of the føotwall unit is very different from that $\bullet$ the hanging wall. It is better described by its low-pressure conditions and by a strong thermal gradient (Fig. 6, white arrøws), and is similar to the low-P intermediate type of Miyashir (1961), characterized by parageneses with andalusite-staurølite-cordierite. An episode of vigorous heating affected most of the Xistral window and is clearly identified in the quartzites, where it gave rise to a pronounce grain growth, initiated in the advanced stages of deformation (Fig. 11).

\subsection{Basal shear zone of the Mondonedo nappe in the footwall unit}

Remnants of a ductile shear zone have been found in the upper parts of the Xistal Quartzite, in tw॰ contiguøus -utcrops that surround a NW-SE-trending synform between Muras and Balsa (Figs. 3 and 7). The structure here is defined by a saddle-f ld geometry formed by interference between the transverse synform and the large

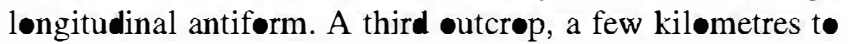

the north, west of Cadramon (Fig. 7), alsø •ccurs on the southern limb of another very open transverse synform.

The mylonitic foliation in the shear zones defines the saddle form of the fold and is at a low angle to thrust faults within the window, which are als affected by the fold interference. This contrasts with the $S_{1}$ foliation below, which is at nearly $\mathbf{9 0}^{\circ}$ to these thrust faults (Fig. 8, crosssection $\mathbf{\mathbf { I }}-\mathbf{I}^{\prime}$ ). Stretching lineation, marked by elongation -f quartz grains, varies frøm E-W t• NW-SE, and shear criteria indicate top-to-the-east kinematics. The quartzite shows a late-kinematic generalized grain grøwth (Fig. 11c) and a quartz $c$-axis fabric (Fig. 12, sample PG-77) discussed in a separate section.

The structural position, always directly underneath slices -f the Mondoñedo nappe (see below), suggests that the mylønitic remnants are relics $\bullet$ the Mondøñedø basal shear zone, preserved in its føotwall. In contrast to the hanging wall unit, the maximum thickness of the shear zone is $1 \mathrm{~km}$ in the footwall, a value attained only in the hinge zone of the Muras-Balsa radial synform and decreasing progressively to zer in the limbs (Fig. 8, section $\mathbf{V}-\mathbf{V}^{\prime}$ ). It seems as if the shear zone was being folded in the radial synform and, at a given moment of the folding process, was cut by the Mondøñedo thrust fault (Fig. 10). The shear zone itself was cut and repeated by late-stage thrust faults, giving rise to

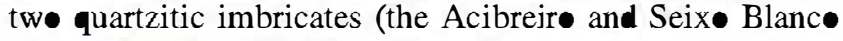
slices; Figs. 7 and 8 ). We will turn back to these pøints later, when describing the $\mathrm{N}-\mathrm{S}$ extension.

\subsection{Lower contractional shear zone}

In the south of the Xistral window and in the Monte Carballosa window, the quartzite became mylonitized the east, below a less-deforme zone where the recumbent folds can be easily mapped (see Figs. 3 and 7). In the Xistral window, the mylonitic foliation is folded in an interference dome (see steregraphic projection in Fig. 7), but is bblique to the Mondoñedo basal thrust (Fig. 8, cross-section IV $\mathrm{IV}^{\prime}$ ) in such a way that unfolding the late longitudinal antiform, it would dip søme $30^{\circ}$ more to the west than the thrust itself. In fact, both shear zones converge to the south - Balsa (Fig. 7). This feature, together with the kinematic criteria indicating top-to-the-east shearing, supports the interpretation of the shear zone as having been a wide ductile thrust.

The mylonitic texture of the quartzites is well marked by quartz ribbons bounded by flat and parallel muscovite crystals. The quartz grains show a late- to post-kinematic generalize grain growth typical of high temperature annealing (Wilsøn, 1973; Bøuchez and Pêcher, 1981) in the lower and middle parts of the shear zone in the Xistral window (sample PG-62; Fig. 11b), but not in the upper part (sample PG-59; Fig. 11a), nor in the Monte Carballosa window where the metamorphic grade remained low through the entire history of deformation. Paths E and D -f Fig. 6, depict the metamorphic ev॰lution of pøints of the 
a

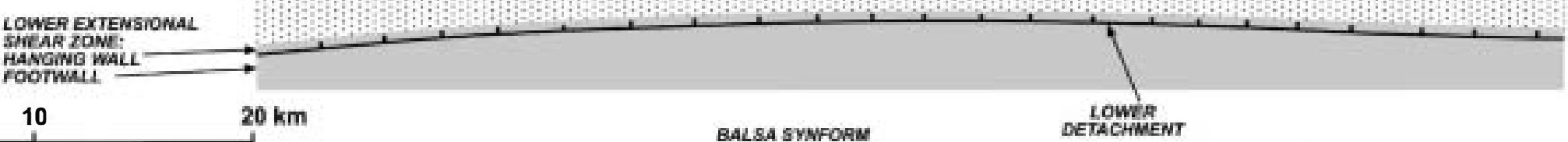

$\mathbf{0}$

$20 \mathrm{~km}$

BALSA SYNFORN

DETACHMENT

XISTRAL QUARTZITE

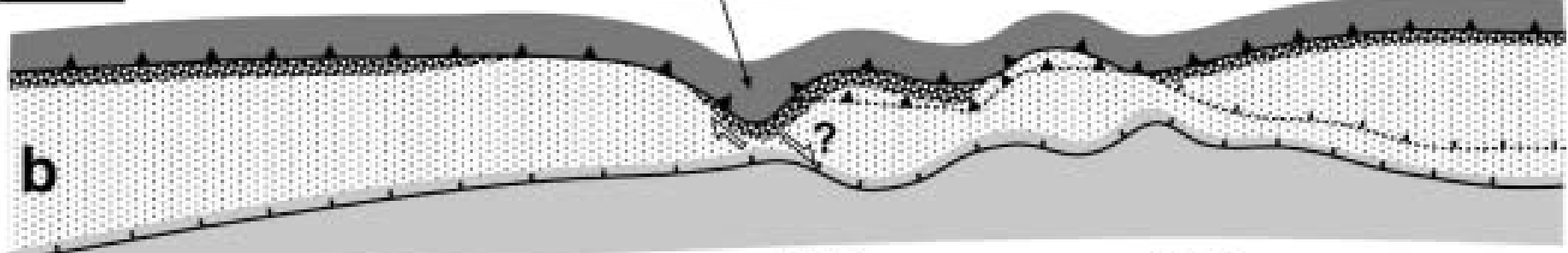

$\Delta-\ldots \Delta$ - ABANDONED

.A........ FUTURE THRUST

$+\quad$ EXTENSIONAL

FUTURE

DETACHMENT

ACTIVE NORMAL

FAULT

FUTURE NORMAL
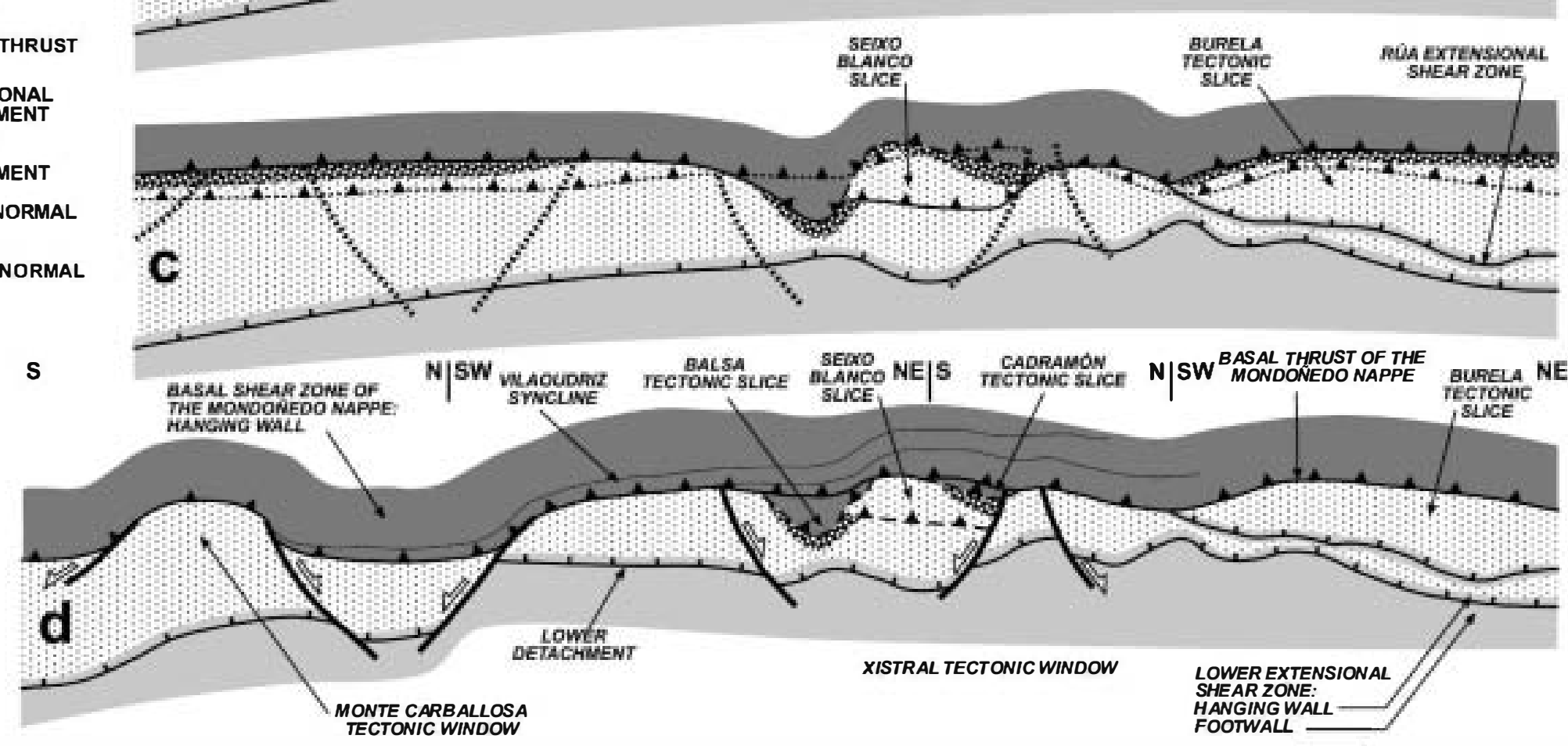

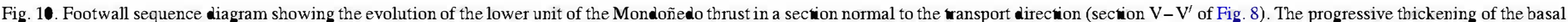

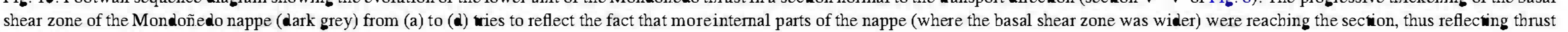
motion contemporaneous with the $\mathrm{N}-\mathrm{S}$ extension. 

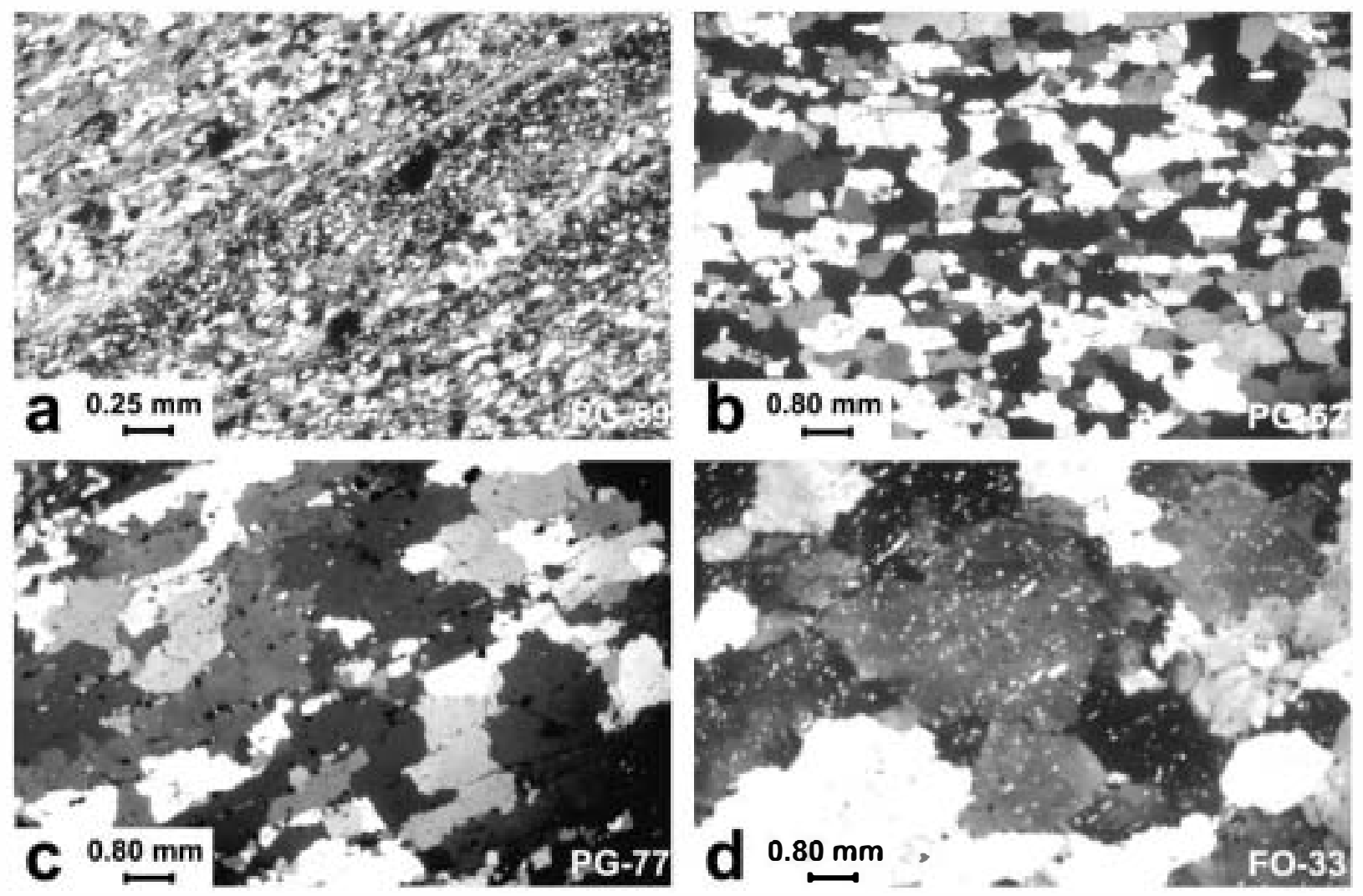

Fig. 11. Microphotographs of mylonitized quatrites in the shear zones of the Xistral tectonic window, showing the effect of heating on grain size. (a) Original fine-grained fabric of the lower con actional shear zone preserved around Vilapedre, in the southern part of the Xistral window (Fig. 7), and corresponding to the upper part of the staurolite-cordierite zone. (b) Mylonitic fabric of the lower contractional shear zone at the limit between the sillimanite and staurolitecordierite zones. Grain growth is very pronounced and evident when comparing with the previous photograph (note the different scales). (c) Fabric of the basal shear zone of the Mondoñe nappe in the footwall unit inside the sillimanite zone. (d) Fabric of the quartzites adjacent to the lower detachment and to the sillimanite-orthoclase zone, showing generalized and exaggerate grain growth. Note the parallel inclusions of white mica corresponding to an older, finegraine foliation. Crosse polarizers. The structural position of the samples is shown in Fig. 12.

f•otwall unit equivalent t• the sampling sites $\bullet P G-62$ and 59, respectively, and Fig. 12 (crøss-section IV-IV') shøws the structural position and quartz $c$-axis fabric of both samples.

\subsection{Lower extensional shear zone and detachment}

The base of the Xistral Quartzite delineates a $\mathrm{N}-\mathrm{S}$ antiform arøund Viveiro, a hamlet in the centre of the tectonic window (n॰t to be confused with the village of

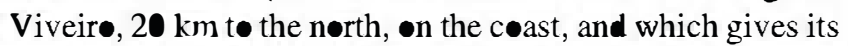
name to the Viveir fault; see Fig. 7). The limit is very smooth, when one considers the fact that the quartzites are

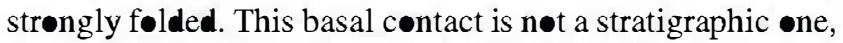
but a detachment fault, associated with which there is a 100-350-m-thick mylonitic shear zone affecting the base of the quartzites above. The mylonites include a new generation of minor recumbent folds with east vergence. These and the asymmetry of sigmøidal bøudins indicate a top-t॰-the-east shearing. As is usually found in the Xistral tectonic window, the quartz-mylonites underwent grain growth, though here it is even more exaggerated (sample FO-33 in Fig. 11d). Individual quartz grains may attain
$10 \mathrm{~mm}$ aløng their long axis, which commønly (but n॰t always) is parallel to the apparent mineral lineation of the rock, marked statistically by the long axes of the quartz grains. The mylonitic f liation is parallel to the detachment, but the layering and the $S_{1}$ f liation in the Xistral Quartzite abøve the shear zone are inclined between 30 and $90^{\circ}$ to it (Fig. 8, crøss-sections $\mathrm{I}-\mathrm{I}^{\prime}$ t• IV $-\mathrm{IV}^{\prime}$ ).

High-grade paragneisses of the sillimanite and the sillimanite-orthøclase zones $\bullet$ ccur beløw the detachment, constituting its footwall. A high-temperature and lowpressure penetrative foliation, roughly parallel to the detachment, characterizes its føotwall, which is als penetratively deformed. Numerous granitic injections evidence partial melting, and the metamorphic associations, characterized by the absence $\bullet$ kyanite and the scarcity $\bullet$ garnet, indicate that high temperatures were associated with relatively low pressures (Fig. 6, path F). N॰ low-T relics are found in the footwall to the detachment, whereas they are cømmon in the quartzites ab॰ve, where parallel inclusions - f very small size (mostly white mica) in large new quartz grains, pøint to a first mylonitic stage developed at low grade conditions (Fig. 1 ld). Alsø, pelitic horizons inside the hanging wall quartzites are low- to medium-grade schists, 


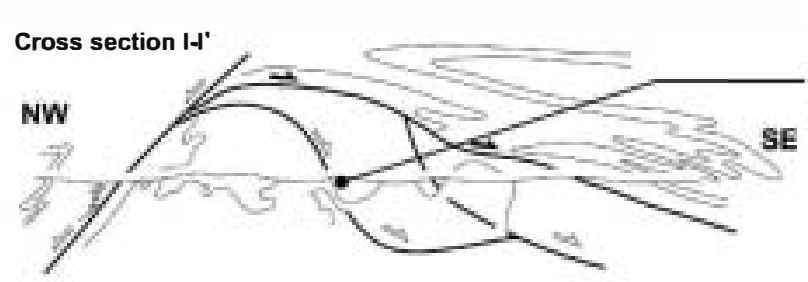

LOWER EXTENSIONAL SHEAR ZONE IN THE HANGING WALL TO No-13 THE LOWER DETACHMENT
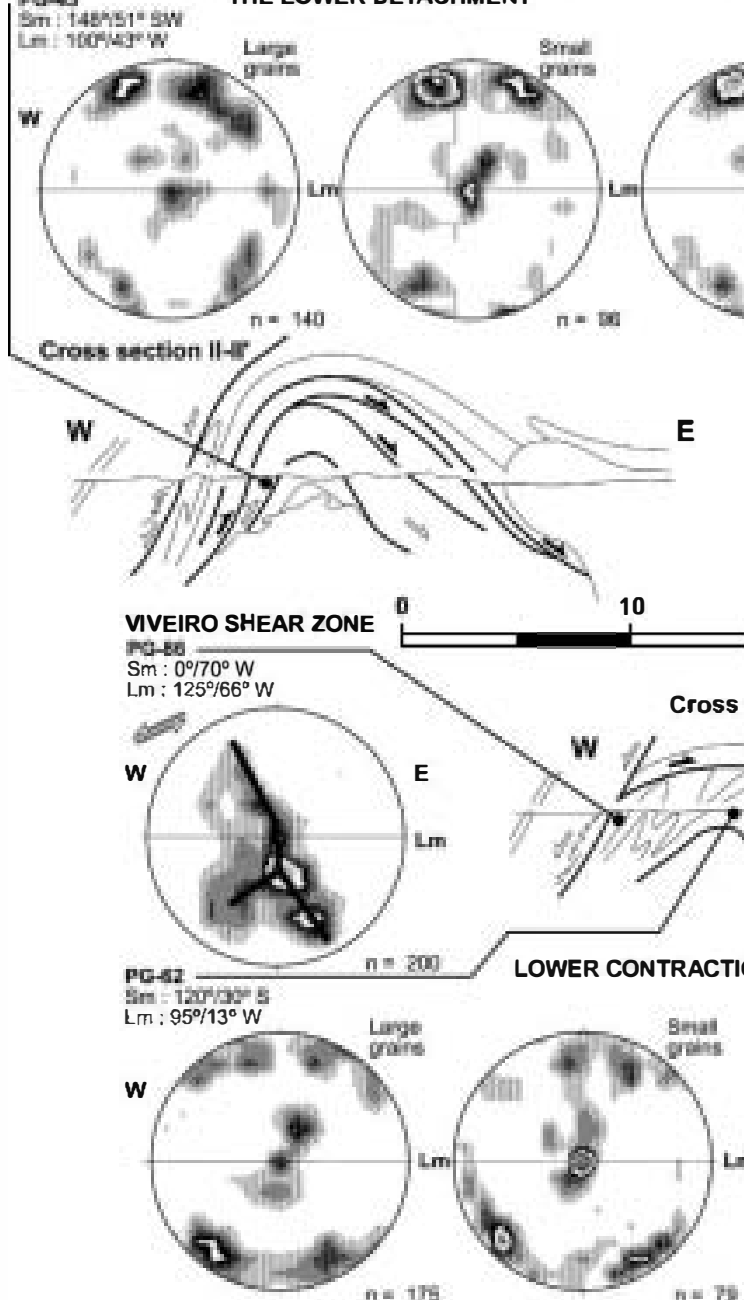

Cross section IV-IV

LOWER EXTENSIONAL SHEAR BASAL SHEAR ZONE OF THE ZONE IN THE HANGING WALL MONDONEDO NAPPE IN THE TO THE LOWER DETACHMENT FOOTWALL TO THE THRUST

ro-j3 $\quad$ PG-77

\begin{tabular}{l|l}
$\mathrm{sm}:$ regiver $W$ & $\mathrm{PG}-77$ \\
$\mathrm{Sm}: 142^{\circ} / 65^{\circ} \mathrm{SW}$
\end{tabular}

E
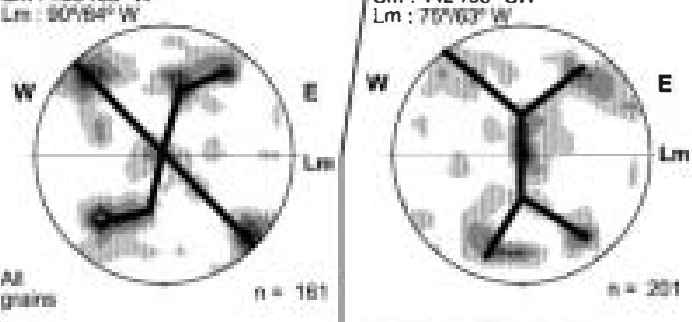

An

Cross section III-III

SE

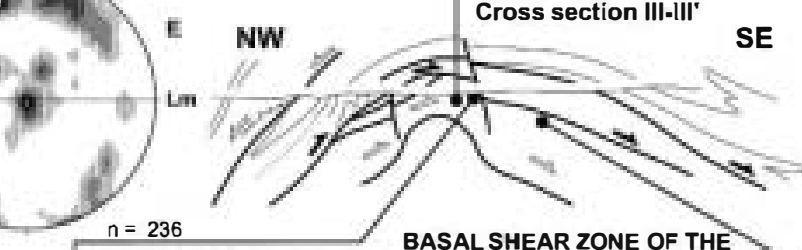

MONDOÑEDO NAPPE IN THE FOOTWALL TO THE THRUST

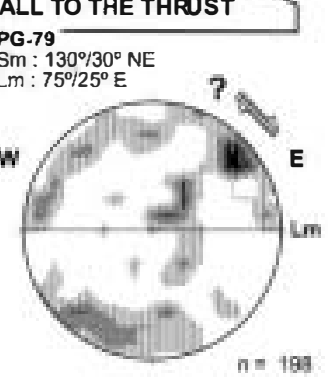

E
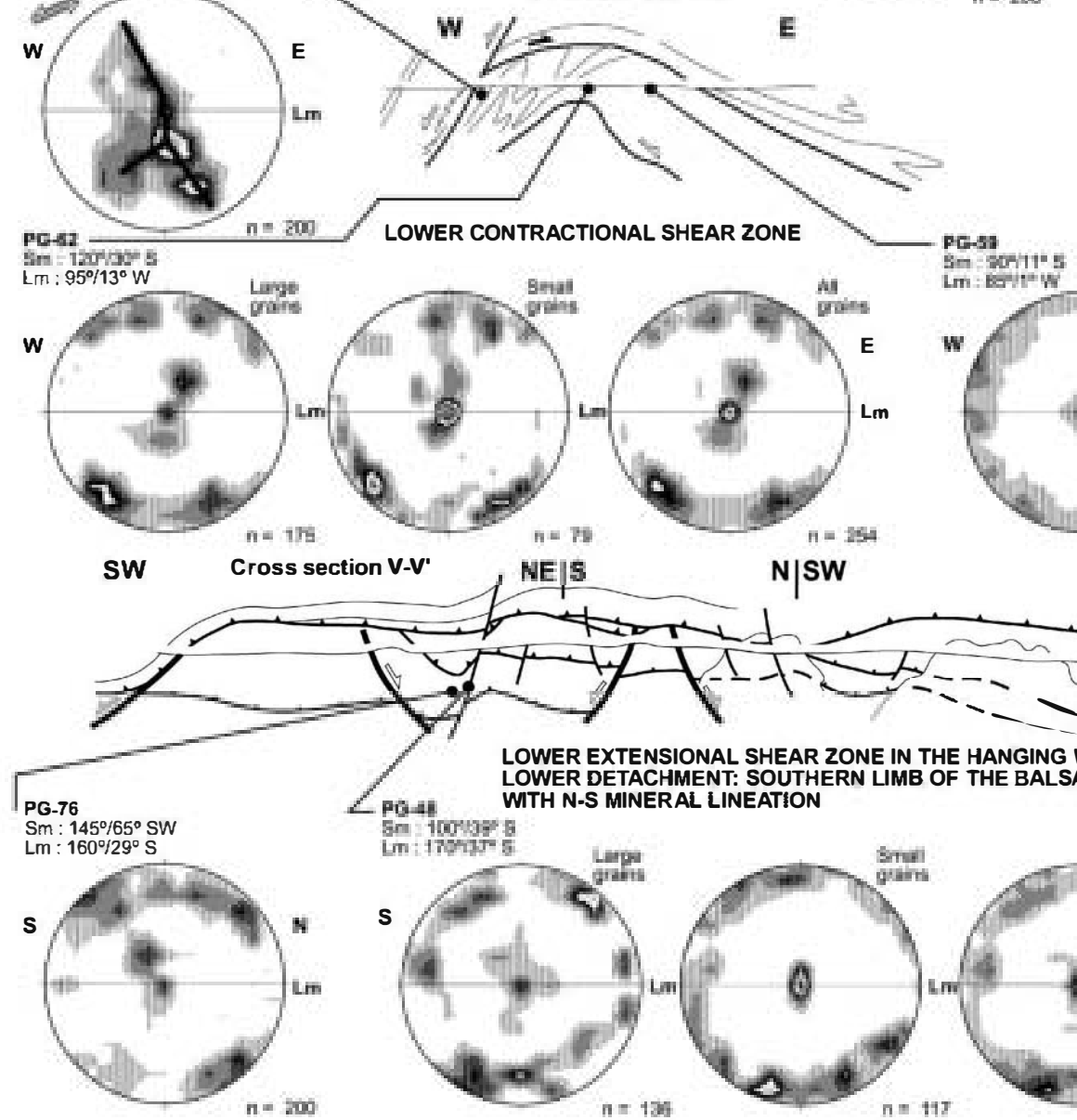

$n=7$

NE $\mid S$

N|SW

NE
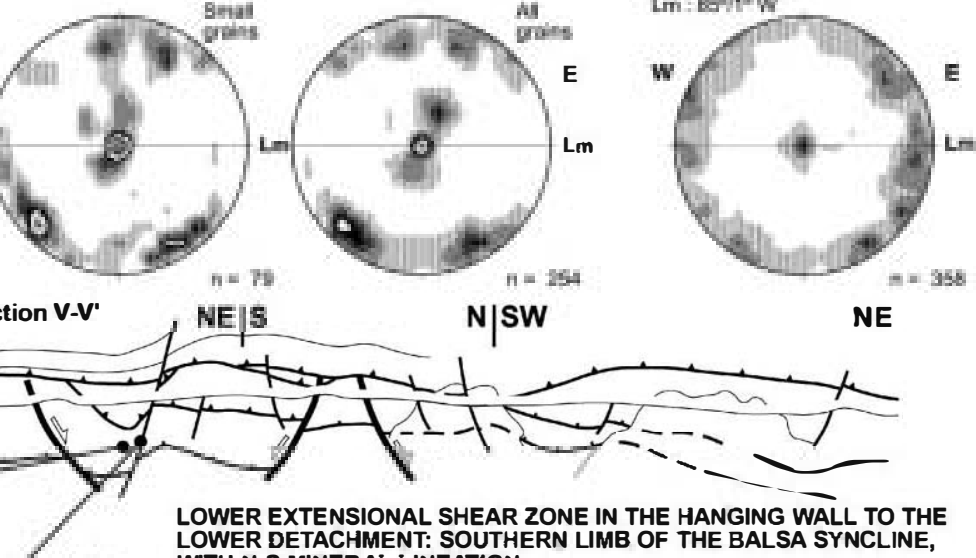

LOWER EXTENSIONAL SHEAR ZONE IN THE HANGING WALL TO THE
LOWER DETACHMENT: SOUTHERN LIMB OF THE BALSA SYNCLINE,
WITH N-S MINERAL LINEATION $\angle$ PG-4E WITH N-S MINERAL LINEATION

5m: 1000395
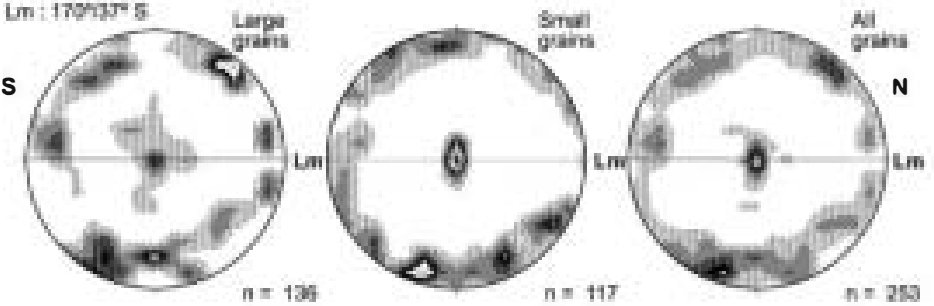

Fig. 12. Quartz c-axis fabrics from the Xis Quartzite mylonitize in the different shear zones. Cross-sections of Fig. 8 are used to locate the analyse samples. 
which were later heated to the sillimanite zone (Fig. 6, path $\mathrm{E})$, but never transformed int paragneisses.

These petrological constraints are used as evidence indicating a jump in metamorphic grade across the detachment, with the omission of part of the metamorphic zoning, pøinting tø an extensional movement (Wheeler and Butler, 1994), coupled with heating of its upper unit with heat transmitted from the lower unit. Yet the $\mathrm{P}-\mathrm{T}$ paths for the upper and the lower units (Fig. 6, paths $\mathrm{E}$ and F, respectively) run almøst parallel. B॰th are nearly isøbaric prograde trajectories, of the type commonly developed in the hanging wall to large extensional detachments (Escuder Viruete et al., 1994, 1997). Considering the $\mathrm{P}-\mathrm{T}$ path $\bullet$ the lower unit (Fig. 6, path F), the possibility arises that this footwall represents in fact the upper part of a deeper zone of crustal thinning and stretching, whose lower part consist of hot material ascending inside the crust.

A series of synkinematic granites, granodiorites and løcally, tonalites, assøciated with ultramafic røcks, intruded the n๑rthern part of the Xistral tectonic window (Figs. 1, 3, 7 and 8), and are collectively described as the Viveirø massif (Galán, 1987). These rocks were deformed, acquiring a lowdipping føliation parallel to the regional high-T and løw-P f•liation of their country røcks. Galán (1987) and Galán et al. (1996) studied these rocks, concluding that the ultramafics have a mantle provenance, and the tonalites and granodiorites include mantle components.

The gelogical map NW of Viveir (Fig. 7) shows that the lower detachment jøins the Mondoñedø basal thrust t• the west (Fig. 8, section $\mathbf{1}-\mathrm{II}^{\prime}$ ). We assume that the thrust was inclined to the west, but depending on how much, the lower detachment would have had an original dip either to the east $\bullet$ r west. On purely geømetrical grøunds, it might be equivalent to either a normal or a reverse fault. However, because the $\bullet$ mission of part $\bullet$ the metamørphic zoning suggests it is an extensional detachment, and shear sense was to the east, we infer it to have originally dipped to the east.

The lower detachment, the assøciated narrow hanging wall shear zone and the widely deformed paragneisses and igneøus rocks below are collectively termed the lower extensional shear zone (Fig. 8). A related structure eccurs in the nørthern part $\bullet$ the Xistral window, west $\bullet$ Rúa, where tw bløcks with west-dipping føliation, are cut by an east-

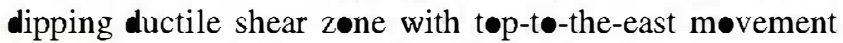
(Fig. 8, section I-I'). Even though both blocks are made up - the Xistral Quartzite, the løwer one is in the sillimanite zøne, whereas the upper $\bullet$ is greenschists facies (Fig. 5). This pøints to the extensional character of the Rúa shear zone, which jøins the Møndønedo thrust fault to the søuth (Fig. 7)

The Rúa extensional shear zone seems dynamically linked to the lower detachment. Its throw is nøt necessarily large, as the thermal gradient associated with the lower detachment is high and the sillimanite and chlorite-biotite

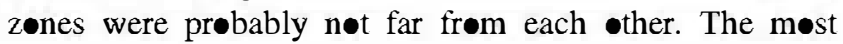

striking feature of this shear zone is the high angle it makes to the foliation in the two bløcks it separates. In both the Mondoñedo thrust sheet and its footwall unit below the Xis ral Quartzite, the bedding and the foliation dips are generally low and, more important, at low angles to the attitude of the thrust fault (Fig. 4). This is not the case in the Xistal Quartzite, however, where the bedding, the $S_{1}$ foliation and the axial surface of first-phase folds dip between 45 and 90*, except inside the ductile shear zones (Fig. 8). In most $\bullet$ the eastern part of the Xistral window, the first foliation makes an angle of nearly $\mathbf{9 0}^{\circ}$ to the thrust

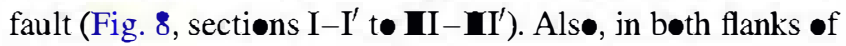
the $\mathrm{N}-\mathrm{S}$ antiform at Viveiro, the planar fabric in the Xistral Quartzite is parallel to its løwer limit only cløse t॰ it, but abøve the shear zøne, bedding and føliation quickly rotate, becoming perpendicular to the lower detachment (Fig. 8, section II- $\mathbf{\mathbf { I }}^{\prime}$ ).

If the high angle between the foliation and either the thrust or the lower detachment is an original feature, the first folds, usually recumbent, would have been vertical in the Xistal Quartzite. The •ther possibility is that this angle resulted from subsequent rotation, and the Rúa extensional shear zone may have allowed the rotation to proceed by domino-style boudinage. This type of boudinage needs weak, ductile layers on both sides to accommodate the rotation of the rigid bløcks. The hot footwall unit of the lower detachment may have worked as the lower one of such ductile layers, whereas the basal shear zone of the Mondoñedo nappe would have been the upper one. At least tw॰ bløcks, separated by the Rúa extensiønal shear zone, røate countercløckwise. An॰ther bløck may have existed to the west $\bullet$ Viveir if the antiform there was nucleated by boudinage. Because folds form at the neck of boudins, the antiform may have resulted from the $\mathrm{E}-\mathrm{W}$ individualization -f a new block during E-W extension. This would explain its nearly $\mathrm{N}-\mathrm{S}$ attitude, søewhat different from the NESW srike of the tectonic window and of the late open folds in the northern part of the Mondoñedo nappe (Fig. 3).

\section{4. $N-S$ extension and the thrust slices}

Megaboudins other than the blocks described in the previous section alsø develøped during nappe emplacement, but related to longitudinal stretching of the Xistal Quartzite. The lower detachment and the basal shear zone of the Mondoñedo nappe are commonly $2000 \mathrm{~m}$ apart, but north $\bullet$ Balsa, they jøin each •ther (Fig. 7), and this •ccurs in the -nly area where $\mathrm{N}-\mathrm{S}$ stretching lineations are seen in the Xis ral Quartzite (Fig. 7; N-S maximum in the sterepløt showing mineral lineation inside the shear zones). Elongation is normal to the føld axis in the inner arc •f the Balsa syncline, a feature compatible with the syncline being the neck of a megaboudin. This interpretation explains why the shear zones that developed in the upper and lower parts of the Xistral Quartzite, apprøach each $\bullet$ ther 
in this area (Fig. 8, section $\mathbf{V}-\mathbf{V}^{\prime}$, below the Balsa slice), and is illustrated in Fig. $10 \mathrm{~b}$.

The subsequent development of $\mathrm{E}-\mathrm{W}$-trending normal faults confirms the $\mathrm{N}-\mathrm{S}$ extension. Inside the Xistral window, three of these faults (thick lines in Figs. 7 and 8, section $\mathbf{V}-\mathbf{V}^{\prime}$ ) crosscut the footwall unit but not the Mondoñedo thrust sheet. The most prominent of these faults, west •f Cadramón, cuts the Seix• Blanc• slice (preserved only in the downthrown søuthern bløck) but is cut by the Mondoñedo thrust fault. The $\mathrm{E}-\mathrm{W}$ fault appears følded by late longitudinal følds, a feature that can be appreciated in the map (Fig. 7) and in an outcrop where a fault-related cataclasite appears folded with a steep axis. Many $\bullet$ ther faults have been mapped, but most of them are late structures, pøst-dating the longitudinal følds. Conversely, these three are early normal faults pre-dating the latest stages of thrusting.

The $\mathrm{N}-\mathrm{S}$ extension, though of limited extent, had an important imprint in the present configuration of the Mondoñed॰ nappe and its footwall unit. The necks of the bøudins and the fault-related grabens have preserved slices of the Mondoñedo nappe that were abandoned in these structural depressions by newly formed faults abøve. This is the case of the Balsa and Cadramon tectonic slices (Figs. 7-9). Conversely, bøudins and horsts were runcated and

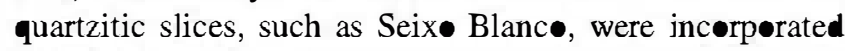
int the thrust sheet.

It has been a common practice in thrust tectonics to use hanging wall sequence diagrams (e.g. Harris, 1970; Elliøtt

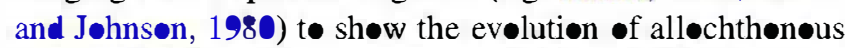
units. The diagrams are successive longitudinal crosssections showing how different units are being incorporated int the hanging wall unit of thrust systems propagating sequentially in a piggy back mode. In the case of the Mondoñedo nappe, several imbricates were abandoned below the currently active thrust fault, sø that a føotwall sequence diagram (Fig. 10) seems appropriate to show the develøpment $\bullet$ thrust slices in relation t$\bullet \mathrm{N}-\mathrm{S}$ extension.

Fig. 10 illustrates both the creation of the Balsa slice after develøpment of the Balsa synform, and how the Sejx॰ Blance slice developed by truncation of a megaboudin North of the Balsa synfom $(a-c)$, itself then being runcated by an early normal fault (c and d) and lately overprinted by the latest Mondoñedo basal thrust fault (d). In addition, t• show how the slices developed sequentially and how they were preserved by the creation of new faults ab॰ve, Fig. 10 explains the origin of the ransverse open folds: they correspond either to the necks of megabøudins, or are 'forced' folds above horsts and grabens bounded by the early E-W normal faults in the føotwall unit. The søuthern limit of the Xistral window and the original north and south boundaries of the Monte Carballosa window, were probably early normal faults, affecting the Xistral Quartzite but not penerating up int the Mondoñedo nappe. The thrust sheet adapted to this evølving føotwall structural top@graphy, and the normal fault planes became part of the thrust surface, acting as lateral ramps during the last stages of thrusting.

\subsection{Quartz c-axis fabrics}

The shear zønes $\bullet$ the Xistral window share a cømmon quartz $c$-axis fabric: a type I crossed girdle (Lister and Williams, 1979; Schmid and Casey, 1986), usually -rthorhømbic (Fig. 12). Often, there is a central part $\bullet$ blique to the mylonitic føliation and sømetimes, the •blique central part of the crossed girdles, or the more populated of the tw girdles, may be taken as kinematic indicators. In all the cases, however, shear sense has been checked with macrøscopic kinematic criteria, such as sigmøidal bøudinage and fold vergence.

The fabrics are similar to those modelled by Lister and Williams (1979) for simple shear sometimes combined with coaxial deformation, and correspond to plane strain

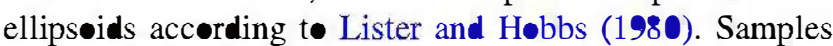
taken outside the shear zones do not show clear crystallographic fabrics.

T• test the influence $\bullet$ the grain grøwth recorded by the quartzites inside the sillimanite zone, separate diagrams were plotted for small and large grains of the same thin sections. Large quartz grains show microinclusions, mostly -f white mica grains, parallel and closely spaced (Fig. 1 ld). They are relics of an earlier fine-grained foliation and, when the grain growth is not exaggerated (Wilson, 1973), that is, not all of the grains reach large sizes, small quartz grains do not include white mica (Fig. 11c) and are viewed either as preserved relics of the pre-heating stage or as recrystallized new grains.

As can be seen in Fig. 12, crystallographic fabrics are similar for both grain sizes, which suggests that this type $\bullet$ $c$-axis fabric existed before the quartz grains grew. Behrmann and Platt (1982) •btained similar diagrams in rocks deformed at low-grade conditions, between 300 and $400^{\circ} \mathrm{C}$. It is quite clear that mylonites developed at relatively low temperatures and were subsequently heated. But it seems that heating was accompanied with further ductile deformation. The largest grains post-date mylonitization in the lower detachment (Fig. 11d) sø that, there, grain growth continued after mylonitization had ceased. However, the large quartz grains often define the mineral lineation. This is the case of the lower contractional shear zone (Fig. 11b), the basal shear zone of the Mondoñed॰ nappe in the footwall unit (Fig. 11c), the lower detachment and the hinge zone of the Balsa syncline, the supposed megabøudin neck of the $\mathrm{N}-\mathrm{S}$ extension. In these cases, the shape fabric of large quartz grains fits the $c$-axis fabric, suggesting that deformation was active during heating.

In sections where the Xistral Quartzite can be traced frøm løw-grade to the sillimanite zone (Fig. 5), the metamorphic grade increases downward, and grain grøwth $\bullet$ ccurs only in the staur-lite-cordierite and sillimanite zones, being generalized and pronounced only in the latter. For instance, 


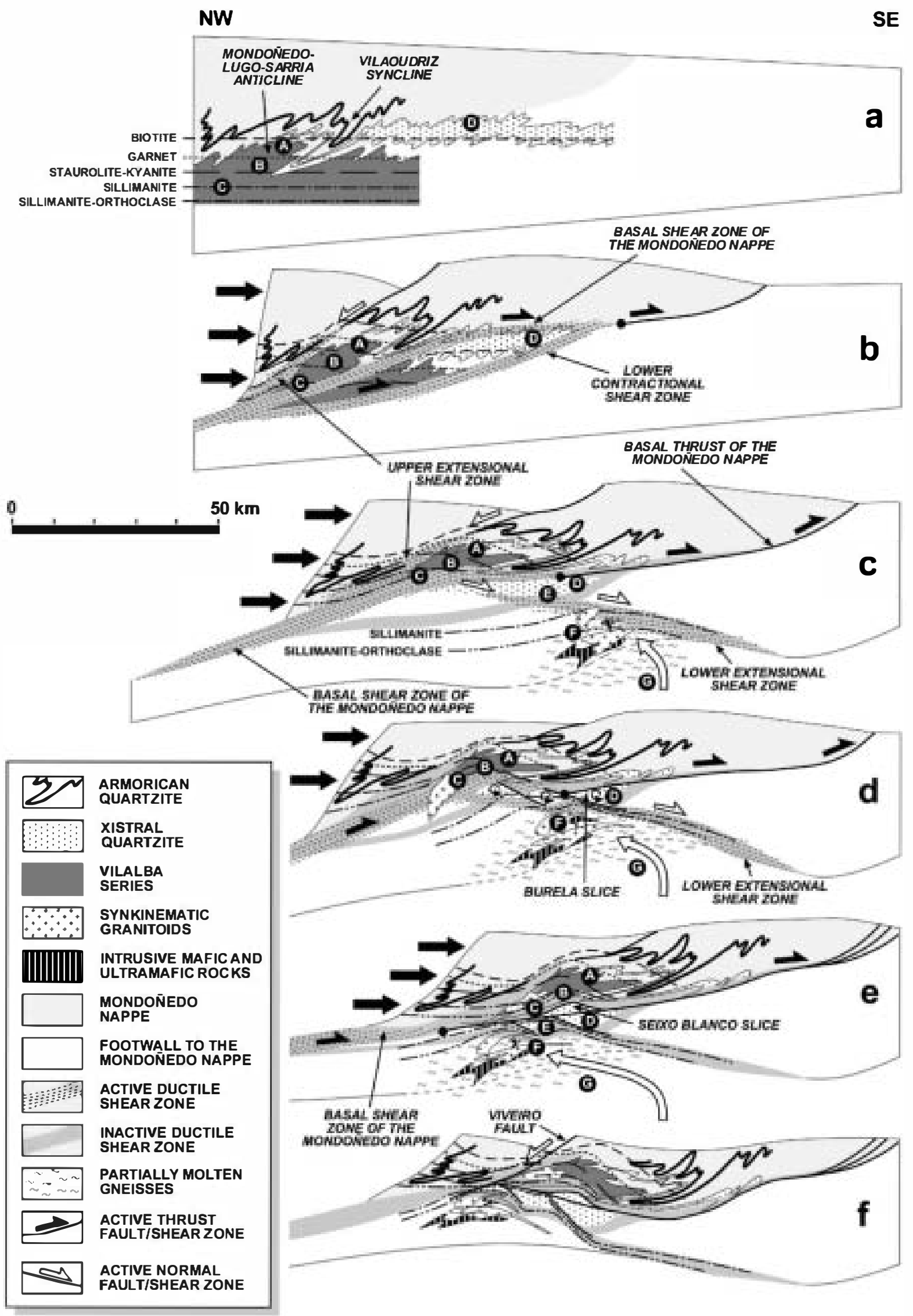


the original fine-grained fabric of the lower contractional shear zone (Fig. 11a) has been preserved arøund Vilapedre, in the southern part of the Xistral window (Fig. 7). This indicates that grain growth was induced by heat transferred from below, and we have seen that heating was coeval with the activity $\bullet$ the lower detachment, which we suggest is an extensional structure. Furthermøre, the simultaneøus shearing and grain growth in the Mondoñedo shear zone (Fig. 11c) demonstrates temporal •verlapping (or alternance) between ductile thrusting and motion of the lower detachment, that is between contractional and extensional structures.

\section{The Viveiro fault}

A normal fault limits the Mondoñedo thrust sheet to the west, crosscutting its hanging wall and footwall units (Figs. 1, 4, 7 and 9). The brittle fault dips between 40 and $60^{\circ}$ west, and has an associated ductile shear zøne, a few hundreds of metres thick, that has not been shown in the maps and crosssections for the sake of clarity. There, the previous regional foliation, either the $S_{1}$ or the $S_{2}$ of the Mondoñedo basal or upper extensional shear zones, appears crenulated by a new, subhørizøntal cleavage. Minør recumbent følds with west vergence and weakly curved hinges, and S-C or ECC microstructures (Platt, 1984), indicate a top-to-the-west møtiøn, with a slight right-lateral compønent (Martínez Catalán, 1985; Martínez et al., 1996). Where the Xistral Quartzite was invelved in the shear zone, a mylonitic foliation developed, whose $c$-axis fabric shows a main girdle $\bullet$ blique to the føliation, supporting the top-t॰-thewest sense of shearing (Fig. 12, sample PG-86).

The upper extensional shear zone and the Viveirø fault

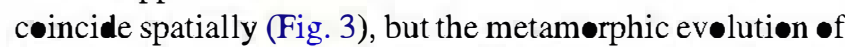
the Mondoñedo thrust sheet demonstates that they were not simultaneous. The upper shear zone developed during early stages $\bullet$ nappe motion, when the thrust sheet was thick and glided abøve the ductile basal shear zone, whereas the Viveir fault cuts the thinned thrust sheet, the brittle thrust fault, and the footwall unit, indicating that it formed when nappe motion had ceased. The Viveir fault $\bullet$ verprints the earlier shear zøne, which was dragged downward to the west by the more steeply-dipping fault (Figs. 4 and 9). It is possible that the fault used parts of the pre-existing weak shear zone tø nucleate and develøp.

The shear zone associated with the Viveirø fault developed under low-grade metamorphic conditions. Kyanite and staurolite presently found around the fault grew during motion of the upper extensional shear zone, when the preserved upper levels of the Mondoñedo nappe were deep enough to fall int the kyanite field, and their decompressive $\mathrm{P}-\mathrm{T}$ path went through this field for a large part of its rajectory (Fig. 6, path A). Martínez Catalán et al. (1990) suggested a throw of $10-12 \mathrm{~km}$ for the Viveiro fault, considering the metamorphic gap: it separates the chlorite

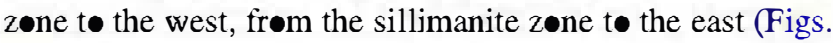
4 and 5). A more precise estimation of the vertical $\bullet$ ffset, based on thermøbarømetry, was given by Reche et al. (1998) as between 4 and $5 \mathrm{kbar}$, roughly equivalent to $15-$ $19 \mathrm{~km}$. This throw is viewed as the result of the tw॰ dip-slip motions: that $\bullet$ the upper extensional shear zone and that the Viveir fault itself. A dip-slip of $5-6 \mathrm{~km}$ is more reasonable for the Viveirø fault alone in the north (Fig. 4, crøss-section $\left.\mathrm{A}-\mathrm{A}^{\prime}\right)$. T• the south, the fault slip decreases progressively, being less than $1 \mathrm{~km}$ in the area of Inciø (Fig. 3).

\section{Absolute and relative timing and structural evolution}

The structural history of the Mondoñedo nappe and its footwall is graphically shown in Fig. 13. The different stages are base on overprinting criteria and crosscutting relationships described in previous sections, which will be recalled to justify the structural evelution. The relative

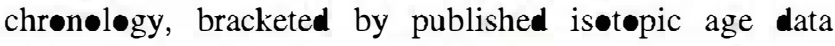
discussed below, is summarized in Fig. 14.

The age of the first deformation phase is constrained by

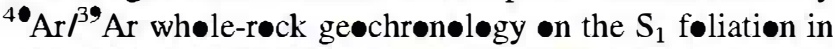
adjacent areas (Dallmeyer et al., 1997). Tøward more internal zones, the first cleavage was dated at $359.3 \pm 0.2 \mathrm{Ma}$ in the western limb of the 'Oll• de Sap•' anticline (Fig. 15) to the south of the Mondoñedo nappe. Toward the foreland, an age of $336.5 \pm 0.3 \mathrm{Ma}$ was -btained near La Espina thrust, at the limit with the external zones to the east (Fig. 15). Frøm these data, the develøpment - recumbent folding in the Mondoñedo nappe can be approximately placed somewhere in the interval between 360 and $335 \mathrm{Ma}$.

Tw॰ samples intended for dating the $S_{1}$ and $S_{2}$ f liations in the Mondoñedo nappe gave ages of $300.0 \pm 1.0$ $\left({ }^{4 \bullet} \mathrm{Ar} /{ }^{39} \mathrm{Ar}\right.$ whøle røck) and $298.2 \pm 0.6 \mathrm{Ma}\left({ }^{40} \mathrm{Ar} /{ }^{39} \mathrm{Ar}\right.$ muscovite), respectively (Dallmeyer et al., 1997). However,

Fig. 13. Structural evolution of the Mondoñe nappe and its footwall unit showing the development of major extensional suctures during thrusting. A black dot at the rear edge of the Mondoñe thrust marks the suggested propagation of the fault into the basal ductile shear zone. The metamorphic isograds have been included. (a) After recumbent folding and equilibration of Barrovian metamorpbism. (b) Early stages of emplacement of the Mondoñedo nappe and coeval extension, relate to the upper extensional shear zone. (c) As before, but extension begins to affect the footwall unit, associated with the ascent of igneous rocks and parially molten gneisses. (d) and (e) Westward motion of the hot, partially molten rocks induces continued activity of the lower extensional shear zone and detachment, and heawng of its hanging wall unit. Note the ascent of the sillimanite isograd into the previous low-grade Xiswal Quartzite, the extension of this unit accomplishe by domino-style boudinage, and the funcation of one of the boudins by the thrust fault, forming the Seixo Blanco slice. (f) The Viveiro nornal fault post-dates the last increments of thrusting 


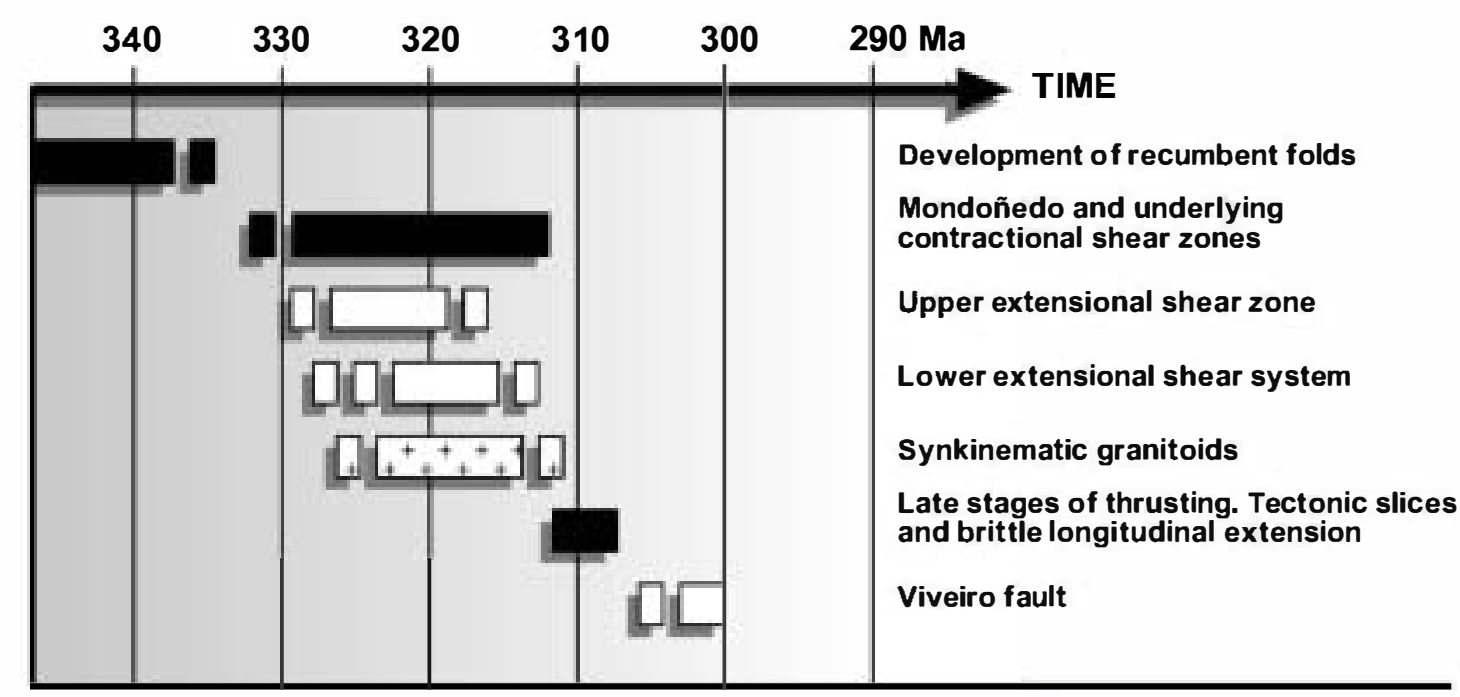

Fig. 14. Tirning of contractional and extensional structures across the study area. Chronology is based on Dallneyer et al. (1997) and Fernández-Suárez et al. (2000).

synkinematic granitøids gave $\mathrm{U}-\mathrm{Pb}$ zircon and monazite ages ranging between 310 and 330 Ma for the massifs $\bullet$

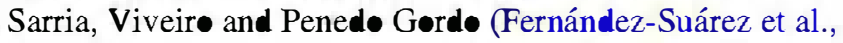
2000). This would suggest that bøth the $S_{1}$ and $S_{2}$ foliations are more than 10 m.y. younger than the granitoids synkinematic with nappe emplacement. A more feasible explanation is that, rather than dating fabric development,

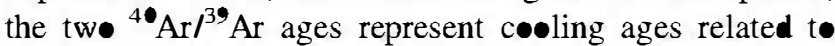
unroofing, and perhaps date the uplift of the nappe by motion on the Viveirø fault.

The Sarria massif is a twø-mica granite intruded in the southern part of the Mondoñedo nappe (Fig. 3) and deformed in its basal shear zone (Martínez Catalán, 1983, 1985). The intrusion als reached the upper extensional shear zone, but is undeformed there (Figs. 3 and 4 , section $B-\mathrm{B}^{\prime}$ ) and assumed to pøst-date this shear zone. Consequently, the age of crystallization of the granite, $313 \pm 2 \mathrm{Ma}$ (Fernández-Suárez et al., 2000), establishes an upper limit for the upper extensional shear zøne, whøse motion pre-dated this age, and alsø a løwer limit for the final emplacement of the thrust sheet (Fig. 14), which continued moving after the granite intrusion. The Penedo Gorde massif, dated at $317_{-5}^{+9}$ Ma (Fernández-Suárez et al., 2000), alsø intruded int• the upper extensional shear zone, but was only deformed by the Viveir fault (Figs. 3 and 7), establishing a lower limit for its motion and, as the Sarria massif, an upper age limit for the upper extensional shear zøne. The Viveirø massif (Figs. 3, 7 and 8) was deformed in the lower extensiønal shear zøne, sø that the $323_{-5}^{+9} \mathrm{Ma}$ age $\bullet$ crystallization •btained by Fernández-Suárez et al. (2000) represents a lower limit for the late activity of this structure.

Postkinematic granitøids have been dated between 285 and $295 \mathrm{Ma}$ (U-Pb method, Fernández-Suárez et al., 2000) and 275 and $285 \mathrm{Ma}\left({ }^{40} \mathrm{Ar} /{ }^{39} \mathrm{Ar}\right.$ method; Dall- meyer et al., 1997). U- $\mathrm{Pb}$ data are more reliable for crystallization ages, and provide an upper limit for thrust tectonic activity: the A Tojiza massif $(295 \pm 2 \mathrm{Ma})$ and the San Ciprián massif $(286 \pm 2 \mathrm{Ma})$ •verprinted the basal shear zone and thrust fault of the Mondoñedo nappe (Fig. 8, sections $\mathrm{I}-\mathrm{I}^{\prime}$ and $\mathbf{\mathbf { I }}-\mathbf{\mathbf { I }}^{\prime}$ ). These same massifs alsø yielded ${ }^{4 \bullet} \mathrm{Ar} /{ }^{39} \mathrm{Ar}$ muscovite ages $\bullet 284$ and $274 \mathrm{Ma}$, respectively, suggesting a time lapse of $10 \mathrm{~m} . \mathrm{y}$. between crystallization and cooling to the closure temperature of argøn in muscovite.

Taking together these data and the mutual relationships between the different structures described in the previous sections, a picture of the structural evølution can be traced.

After a first episode of recumbent folding, crustal thickening and burial, loosely constrained between 360 and $335 \mathrm{Ma}$, a Barrovian metamorphic zoning was established and equilibrated (Fig. 13a and Fig. 6, paths A, B and C, prograde part of grey arrows, mostly dashed). The Xistral Quartzite occupied, at that time, a relatively shallow position.

In the next 30 million years, the contractional ductile shear zones developed. The more internal parts of the thrust sheet initiated their exhumation along the basal shear zone of the Mondoñedo nappe (Fig. 13a and b) from a depth of $38-45 \mathrm{~km}$ (Arenas and Martínez Catalán, 2003). While thrust motion induced crustal thickening, the thrust sheet became thinned by the upper extensional shear zone, and the lower extensional detachment developed in the footwall unit (Fig. 13c). An upper age limit for the extensional activity in the nappe is provided by the Sarria and Penedo Gordo massifs (313 \pm 2 and $317_{-5}^{+9} \mathrm{Ma}$, respectively; Fernández-Suárez et al., 2000), which were nøt affected by the upper extensional shear zone.

Heat accumulation due to crustal thickening and, 


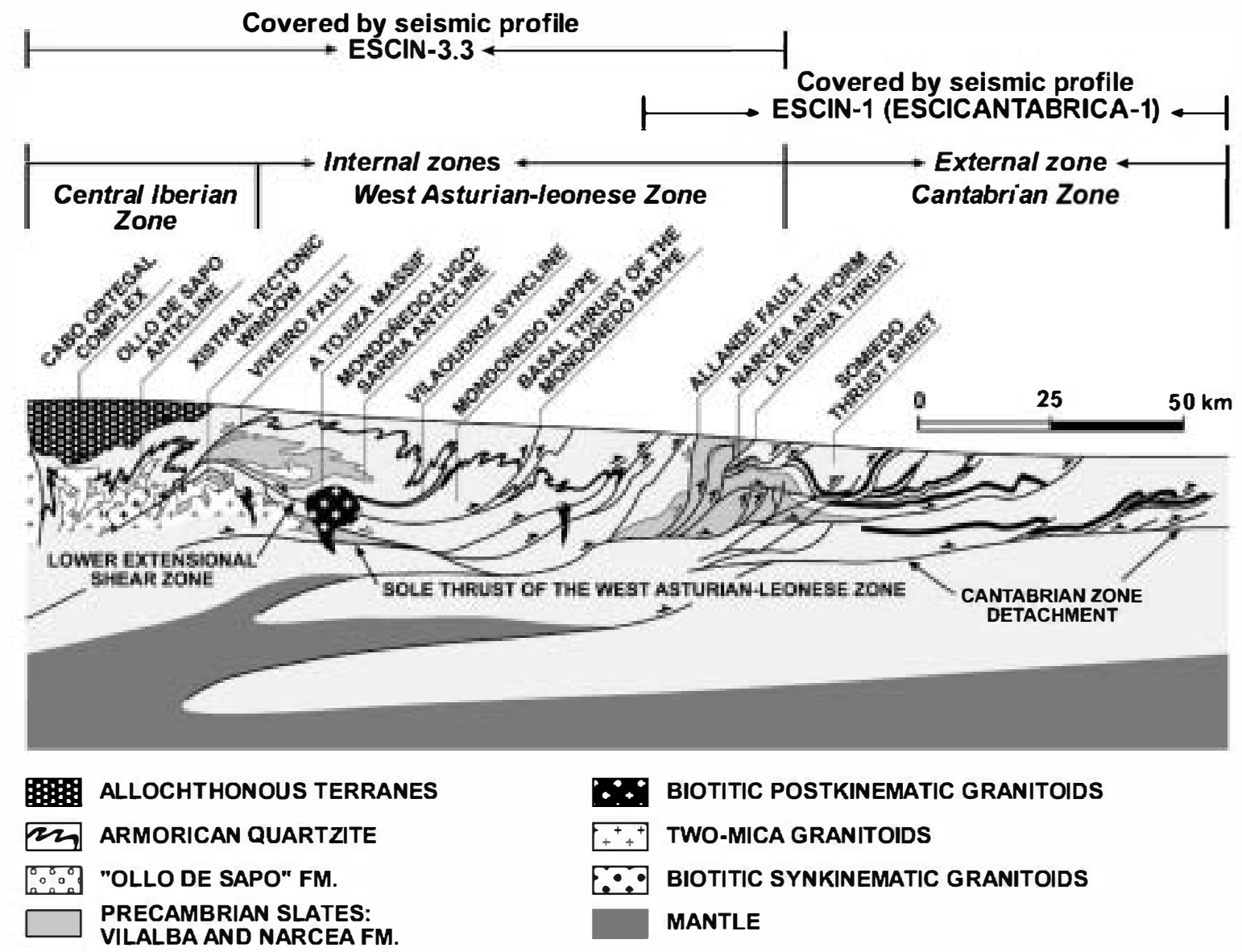

Fig. 15. The swucture of the Variscan wedge, as suggested at the end of convergence, based on sufface geology and geophysics.

probably, t• advention of mantle-derived røcks, may have triggered the development of the lower extensional shear zone, which juxtaposed deep-seated hot rocks against the -verlying and relatively cold Xistral Quartzite. The thick and competent quartzitic layer might have acted as a screen, channelling the viscous flow of ascending buoyant material. Partially mølten crustal and subørdinate mantle røcks trying to open their way upward (Fig. 6, path G) would have been

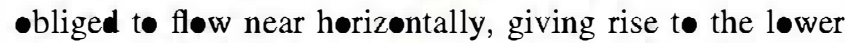
extensional detachment (Fig. 13c-e). Heating was very strong in the footwall to the Mondoñedo nappe (Fig. 6, paths $\mathrm{E}$ and $\mathrm{F}$ ), and synkinematic igneous rocks intruded in the footwall to the lower detachment.

The heat ansmitte from below annealed the mylonitic quartzites of the hanging wall to the detachment, and als• those of the two contractional shear zones in the Xistral tectonic window, that had previously developed low-grade mylonites (Fig. 11). Consequently, we assume that the lower detachment post-dated part of the ductile shearing in the Mondøñedo and lower contractional shear zones. However, it seems that heating was accompanied with further ductile

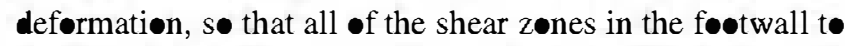
the Mondoñedo thrust fault were heated while being still active. Furthermore, as long as the Mondoñedo thrust and associated tectonic slices cut the annealed mylonites, we infer that thrust movement continued after the activity aløng the lower detachment had ceased.

Once thinned, the Mondoñedo nappe moved as a relatively cold thrust sheet, less than $20 \mathrm{~km}$ thick, •verthrusting its present footwall unit, which registered a moderate heating and pressurization until the $\mathrm{P}-\mathrm{T}$ conditions at the bottom of the hanging wall (Fig. 6, path C)

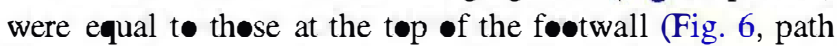
D). The thrust developed as a discrete fault close to the ductile-brittle transition, propagating inte the previous ductile shear zone and preserving most $\bullet$ it in the hanging wall (Fig. 13c-e), but alsø a portion in the footwall (Fig. 7).

The Xistral Quartzite underwent $\mathrm{E}-\mathrm{W}$ and $\mathrm{N}-\mathrm{S}$ extension coeval with the late stages of nappe emplacement. Ductile extension in the $\mathrm{E}-\mathrm{W}$ direction included dominostyle rotation of individual bløcks (Fig. 13d). N-S extension was locally ductile but most generally brittle (Fig. 10). In both cases, asperities created by the individual blocks, equivalent to megaboudins, were cut by the late thrust fault, giving rise to lens-shaped tectonic slices (Figs. 10 and 13e). However, this was not always the case, because the faults bounding horsts and grabens created by the $\mathrm{N}-\mathrm{S}$ extension acted as lateral ramps, giving rise to the transverse $\mathrm{E}-\mathrm{W}$ rending $\bullet$ pen følds in the thrust sheet (Figs. 3, 7,9 and 10).

Once thrust motion had ceased, the Viveirø fault 
developed, crosscutting the Mondoñedo thrust sheet and its aut•chthøn (Fig. 13f).

\section{Implications for the dynamics of the Variscan orogenic wedge}

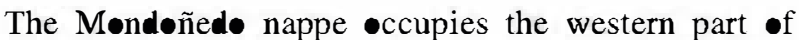
the West Asturian-leonese Zone, which is one of the internal zones of the Variscan belt in the NW Iberian Massif (Julivert et al., 1972). T• the east, the Cantabrian Zøne is a foreland thrust belt representing an external zone of the massif. Fig. 15 sketches the final stage of the or genic evolution in the Mondoñedo nappe and surrounding areas, as deduced from deep seismic reflection profiles (Pérez-Estaún et al., 1994; Ayarza et al., 1998), and structural information from surface ge $\bullet$ gy after Marc (1973), Bastida et al. (1982, 1986), Pérez-Estaún et al. (1988, 1991), Martínez Catalán et al. (1990), Gutiérrez-Aløns• (1996), and this work.

A deep reflection seismic profile acquired on land in the Cantabrian Zøne (ESCN-1) shows a wedge geometry and a relatively shalløw søle thrust, confirming the thin-skinned style of deformation in this zone (Pérez-Estaún et al., 1994). In another deep seismic profile (ESCIN-3.3) acquired - ffshore north of the study area, a crustal-scale thrust is suggested by a series $\bullet$ reflections beløw the Mondoñed nappe, which continue west, down-dip int the løwer crust and the Moho discontinuity (Ayarza et al., 1998). These structures, called, respectively, the Cantabrian Zone detachment and the søle thrust of the West Asturian-leonese Zøne, have been incorporate int Fig. 15. Furthermøre, the ESCIN-3.3 profile shows twe or three bands with high reflectivity in the lower half of the crustal section underlying the Mondoñedo nappe. Ayarza et al. (1998) interpreted them as lower crust-mantle imbrications, because refraction seismics and a magnetic an॰maly suggest the existence of mafic and ultramafic recks relatively close to the surface (Aller et al., 1994; Córdoba et al., 1987; Ayarza et al., 1998).

All the geological and geophysical data can be readily integrated with the structural evidence to draw an image

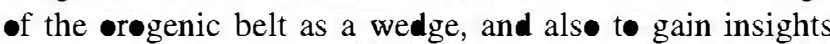
int its evølution. The fact that the structural style of the Cantabrian Zone is thin-skinned suggests that its basement must have been underthrust beneath the West Asturian-leonese Zone. For the 90-km-long ESCIN-1 profile, the accumulated displacement $\bullet$ the thrusts faults has been estimated as $150 \mathrm{~km}$ (Pérez-Estaún et al., 1994), implying that another $60 \mathrm{~km}$ should have been moved to the west. The Cantabrian Zøne continues at least $80 \mathrm{~km}$ eastward of the end of the seismic profile, sø that the total length of the underthrust basement should be more. Thin-skinned tectonics were active in the Cantabrian Zøne until Kasimøvian times (Pérez-Estaún et al., 1988), i.e. until $300 \mathrm{~m} . \mathrm{y}$. ag•, and this is the age suggested for the Viveirø fault by ${ }^{40} \mathrm{Ar} /{ }^{39} \mathrm{Ar}$ cooling ages in the Mondoñedo nappe (Dallmeyer et al., 1997). Furthermore, the lowermost band with high reflectivity in profile ESCN-3.3, situated at a depth of 34-41 km, can be followed to approximately the vertical of the Viveirø fault.

According to these data, a wedge shape is quite reasønable for this area $\bullet$ the Variscan belt. The innermøst part $\bullet$ the original basement $\bullet$ the Cantabrian Zøne would have acted as the lower boundary of the wedge during the late stages of convergence, and its underthrusting would have been active until around $\mathbf{3 0 0}$ m.y. ag・. In spite of being subjected to continuøus (or episølic) shortening (Fig. 14), tw extensional shear zones developed inside the wedge, probably to compensate gravitational gradients (Hodges et al., 1996) created by its internal dynanics and thermal evølution. The fact that the lower extensional shear zone developed beneath the Mondoñedo nappe during its emplacement confirms that its basal thrust was a contrational fault inside the wedge, and nøt its basal bøundary.

Underplating probably played a røle in the extensional activity, as frontal accretion to the east $\bullet$ ccurred in a thinskinned mode; that is, invelved only the sedimentary prism. Westward underthrusting of part of the the external basement seems to have occurred partially beneath the lower continental crust and the subcontinental mantle of the internal zones (Fig. 15). Buøyancy due to this density inversion may be responsible for increasing the vertical stress and creating topographic relief. The same effect would have been induced by partial melting deep in the crust. In addition, prolonged heating, mostly due to orøgenic thickening but possibly with a magmatic contribution from the mantle (Galán et al., 1996), would have lowered the viscosity $\bullet$ the middle and løwer crust, preparing it t• fløw easily in response to the internal stress field. If vertical stresses were dominant in the deep parts of the wedge, the viscous flow would have extended it, mostly transversally, i.e. in the $\mathrm{E}-\mathrm{W}$ direction (althøugh søme longitudinal extension alsø tøok place), inducing a decrease in the wedge taper.

The lower extensional shear zone may represent a transition between a low-viscosity, flowing crustal layer and a strønger crust abøve. In fact, this brøad structure, whose lower limit does not øutcrøp, might have accømmodated much of the internal strain needed tø extend and sharpen the wedge. Conversely, the upper extensional shear zone probably developed in the relatively strong part $\bullet$ the

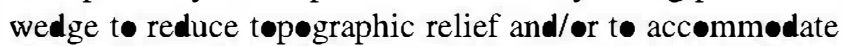
the $\mathrm{E}-\mathrm{W}$ extension undergone by deeper parts. Extension in both shear zones took place while convergence continued, as demonstrated by crosscutting relationships of the late Mondeñedo thrust (Figs. 13 and 14). The Viveire fault, post-dating nappe emplacement, could reflect the latest stages of convergence in the Cantabrian Zone. 


\section{Conclusions}

Vertical shortening and extension occurred in both the hanging wall and the footwall to the Mondoñedo thrust fault synkinematically with thrusting, as shown by crosscutting structural relationships and overprinting metamorphic criteria from tw extensional shear zones. Extension was mostly transversal to the or genic trend, but subordinate longitudinal extension induced normal faulting in the footwall unit to the Mondoñedo nappe, and some of these faults were used as lateral ramps in the latest stages of thrusting.

Using published geological and geophysical data, the complex 3D structural evolution deduced for the Mondoñedo nappe and its autochthon is viewed in a wider regional context, as forming part of an or genic wedge active during most of the Carboniferøus in the NW Iberian Massif. In its late stages, gliding of the wedge could have taken place $\bullet$ ver the presently missing part of the original basement of the foreland thrust belt, which should have been carried beneath the internal zones while its sedimentary cover was being peeled off and imbricated in the front of the wedge.

Heterogeneity characterize the internal deformation of the wedge, with the strain partitioned int structures of different significance. In the case examined in this paper, a major thrust led the local kinematics, overprinting all the extensional structures developed, except the last. This seems to reflect the regional stress field, clearly dominated by plate convergence. However, heat accumulation resulting from crustal thickening and magmatic underplating weakened the deep parts of the wedge, giving rise to a viscous flow that accommodated its extension, induced by gravitational instabilities. The lower extensional shear zone probably represents the transition between a low-viscosity flowing mass and an overlying, more viscous structural level, with the strain being concentrated in an important litholøgical boundary, the base of the competent Xistral Quartzite. The upper extensional shear zone, developed in relatively higher and stronger parts of the wedge, would result frøm E-W stretching, gravitational cøllapse or bøth.

\section{Acknowledgements}

Dennis Brown and Chris Wibberley are sincerely acknowledged for their critical reviews of the early version -f the manuscript. Their clever comments and suggestions and the exhaustive correction of English grammar helped to improve the quality of the paper.

\section{References}

Aller, J., Bastida, F., 1993. Anatomy of the Mondoñedo Nappe basal shear zone (NW Spain). Journal of Structural Geology 15, 1405-1419.

Aller, J., Zeyen, H.J., Pérez-Estaún, A., Pulgar, J.A., Parés, J.M., 1994. A
2.5D interpretation of the eastern Galicia magnetic anomaly (northwestern Spain): geodynamical implications. Tectonophysics 237, 201-213.

Aranguren, A., Tubía, J.M., 1992. Swuctural evidence for the relationship between thrusts, extensional faults and granite intrusions in the Variscan belt of Galicia (Spain). Journal of Smuctural Geology 14, $1229-1237$.

Arenas, R., Marnínez Catalán, J.R., 2003. Low-P metamorphism following a Barrovian-type evolution. Complex tectonic controls for a common wansition, as deduce in the Mondonedo thrust sheet (NW Iberian Massif). Tectonophysics in press.

Ayarza, P., Marínez Catalán, J.R., Gallart, J., Dañobeitia, J.J., Pulgar, J.A., 1998. Estudio Sísmico de la Corteza Ibérica Norte 3.3: a seismic image of the Variscan crust in the hinterland of the NW Iberian Massif. Tectonics 17, 171-186.

Bastida, F., Pulgar, J.A., 1978. La esmuctura del Manto de Mondoñedo en re Burela y Tapia de Casariego (Costa Cantábrica, NW de España) Trabajos de Geología, Universidad de Oviedo 14, 75-124.

Bastida, F., Marcos, A., Marquínez, J., Martínez Catalán, J.R., PérezEstaún, A., Pulgar, J.A., 1982. Mapa Geológico Nacional, Instituto Geológico y Minero de España, sheet 1, La Conuña, scale 1:200,000.

Bastida, F., Martínez Catalán, J.R., Pulgar, J.A., 1986. Structural, metamorphic and magmatic history of the Mondonedo nappe (Hercynian belt, NW Spain). Journal of Swuctural Geology 8, 415-43.

Beaumont, C., Jamieson, R.A., Nguyen, M.H., Lee, B., 201. Himalayan tectonics explaine by ex usion of a low-viscosity crustal channel couple to focused surface denudation. Nature 414, 738-742.

Behrmann, J.H., Platt, J.P., 1982. Sense of nappe emplacement from quartz c-axis fabrics; an example from the Beric Cordilleras (Spain). Earth and Planetary Science Letters 59, 208-215.

Block, L., Royden, L.H., 1990. Core complex geomeries and regional scale flow in the lower crust. Tectonics 9, 557-567.

Bouchez, J.L., Pêcher, A., 1981. The Himalayan Main Central Thrust Pile and its quartz-rich tectonites in Central Nepal. Tectonophysics 78 , 23-50.

Burchfiel, B.C., Royden, L.H., 1985. North-south extension within the convergent Himalayan region. Geology 13, 679-682.

Burg, J.P., Bnmel, M., Gapais, D., Chen, G.M., Liou, G.H., 1984 Defornation of leucogranites of the crystalline Main Central Sheet in southern Tibet (China). Journal of Structural Geology 6, 535-542

Burg, J.P., Van Den Driesche, J., Bnm, J.P., 1994. Syn- to post-thickening extension: mode and consequences. Compte Rendue de la Académie des Sciences, Paris 319, 1019-1032.

Butler, R.W.H., 1982. Hanging wall swain: a function of duplex shape and footwall topography. Tectonophysics 88, 235-246.

Capdevila, R., 1969. Le métamorphisme régional progressif et les granites dans le segment hercynien de Galice nord oriental (NW de l'Espagne). Ph.D. Thesis, Université de Montpellier.

Clark, M.K., Royden, L.H., 2000. Topographic ooze: building the eastern margin of Tibet by lower crustal flow. Geology 28, 703-706.

Córdoba, D., Banda, E., Ansorge, J., 1987. The Hercynian crust in northwestern Spain: a seismic survey. Tectonophysics 132, 321-333.

Costa, S., Rey, P., 1995. Lower crustal rejuvenation and growth during post-thickening collapse: Insights from a crustal cross section through a Variscan metamorphic core complex. Geology 23, 905-908.

Coward, M.P., 1982. Surge zones in the Moine thrust of NW Scotland Journal of Swuctural Geology 4, 247-256.

Dahlen, F.A., Suppe, J., Davis, D., 1984. Mechanics of fold-and-thrust belts and accrenary wedges: cohesive Coulomb theory. Journal of Geophysical Ressearch 89, 10087-10101.

Dahlstrom, C.D.A., 1970. Structural geology in the eastern margin of the Canadian Rocky Mountains. Bulletin of Canadian Peroleum Geology $18,332-4 \cdot 6$.

Dallmeyer, R.D., Martínez Catalán, J.R., Arenas, R., Gil Ibarguchi, J.I., Gutiérrez Alonso, G., Farias, P., Aller, J., Bastida, F., 1997 Diachronous Variscan tectonothermal activity in the NW Iberian 
Massif: evidence from ${ }^{4} \mathrm{Ar} /{ }^{39} \mathrm{Ar}$ dating of regional fabrics. Tectonophysics 277, 31-337.

Davies, H.L., Warren, R.G., 1988. Origin of eclogite-bearing, domed, layered metamorphic complexes ("core complexes") in the D'Enwecasteaux Islands, Papua New Guinea. Tectonics 7, 1-21.

Davis, D., Suppe, J., Dablen, F.A., 1983. Mechanics of fold-and-tbrust belts and accretionary wedges. Journal of Geophysical Research 88 , $1153-1172$

Dewey, J.F., 1988. Extensional collapse of orogens. Tectonics 7, $1123-1139$

Diemich, D., Casey, M., 1989. A new tectonic model for the Helveric nappes. In: Coward, M.P., Dietrich, D., Park, R.G. (Eds.), Alpine Tectonics. Geological Society Special Publication 45, pp. 47-63.

Elliott, D., Jolmson, M.R. W., 1984. Swuctural evolution in the northern part of the Moine tbrust belt, NW Scotland. Transactions of the Royal Society of Edinburgh, Earth Sciences 71, 69-96.

England, P.C., 1983. Some numerical investigations of large scale continental deformation. In: Hsü, K.J., (Ed.), Mountain Building Processes, Academic Press, London, pp. 129-139.

Escuder Viruete, J., Arenas, R., Marínez Catalán, J.R., 1994. Tectonothermal evolution associate with Variscan crustal extension in the Tormes Gneiss Dome (NW Salamanca, Iberian Massif, Spain). Tectonophysics 238, 117-138.

Escuder Viruete, J., Indares, A., Arenas, R., 1997.P-T path determinations in the Tormes Gneissic Dome, NW Iberian Massif, Spain. Journal of Metamorphic Geology 15, 645-663.

Fernández-Suårez, J., Dunning, G.R., Jemner, G.A., Gutiérrez-Alonso, G., 2000. Variscan collisional magmatism and deformation in NW Iberia constraints from U-Pb geochronology of granitoids. Journal of the Geological Society, London 157, 565-576.

Fossen, H., 1992. The role of extensional tectonics in the Caledonian of south Norway. Journal of Swuctural Geology 14, 1033-1 46.

Fossen, H., 2000. Extensional tectonics in the Caledonides: synorogenic or postorogenic? Tectonics 19, 213-224.

Galán, G., 1987. Las rocas graníticas del Macizo de Vivero en el sector Norte (Lugo, NO de España). Corpus Geologicum Gallaeciae, $2^{\mathrm{a}}$ Serie, vol. 3

Galán, G., Pin, C., Duthou, J.L., 1996. Sr-Nd isotopic record of multi-stage interactions between mantle-derived magmas and crustal components in a collision context-the ul wamafic-granitoid association from Vivero (Hercynian belt, NW Spain). Chemical Geology 131, 67-91.

Gutierrez-Alonso, G., 1996. Strain partitioning in the footwall of the Somie Nappe: suctural evolution of the Narcea Tectonic Window, NW Spain. Journal of Swuctural Geology 18, 1217-1229.

Harris, L.D., 1970. Details of thin-skinne tectonics, in parts of Valley and Ridge and Cumberland Plateau provinces of the southern Appalachians. In: Fisher, G.W., Petrijolm, F.J., Read, J.C., Weaver, K.N. (Eds.), Studies of Appalachian Geology: Central and Southem, Interscience, New York, pp. 161-173.

Hatcher, R.D. Jr, Hooper, R.J., 1992. Evolution of crystalline thrust sheets in the internal parts of mountain chains. In: McClay, K.R., (Ed.), Thrust Tectonics, Chapman \& Hall, London, pp. 217-233.

Hatcher, R.D. Jr, Williams, R.T., 1986. Mechanical model for single thrust sheets. Part I. Taxonomy of crystalline thrust sheets and their relationships to the mechanical behaviour of orogenic belts. Geological Society of America Bullein 97, 975-985.

Hodges, K.V., Walker, J.D., 1992. Extension in the Cretaceous Sevier orogen, North American Cordillera. Geological Society of America Bulle in 104, 560-569.

Hodges, K.V., Parrish, R.R., Searle, M.P., 1996. Tectonic evolution of the central Annapurna Range, Nepalese Himalayas. Tectonics 15 , 1264-1291.

Jolivet, L., Goffé, B., Bousquet, R., Oberhänsli, R., Michard, A., 1998 Detachments in high-pressure mountain belts, Tethyan examples. Earth and Planetary Science Letters 160, 31-47.

Julivert, M., Fontboté, J.M., Ribeiro, A., Conde, L., 1972. Mapa Tectónico de la Península Ibérica y Baleares. Instituto Geológico y Minero de España, Madrid, scale 1:1,000,000

Lister, G.S., Hobbs, B.E., 198. The simulation of fabric development during plasic deformation and its application to quartate: the influence of deformation history. Journal of Swuctural Geology 2, 355-371.

Lister, G.S., Williams, P.F., 1979. Fabric development in shear zones: theore concals and observed phenomena. Journal of Structural Geology 1, 283-297.

Marcos, A., 1973. Las Series del Paleozoico Inferior y la estructura herciniana del occidente de Asturias (NW de España). Trabajos de Geología, Universidad de Oviedo 6, 1-113.

Marínez, F.J., Carreras, J., Arboleya, M.L., Dietsch, C., 1996. Structural and metamorphic evidence of local extension along the Vivero fault coeval with bulk crustal shortening in the Variscan chain (NW Spain). Journal of Structural Geology 18, 61-73.

Martínez Catalán, J.R., 1984. L'apparition du chevauchement basal de la nappe de Mondoñe dans le dôme Lugo (Galice, Espagne). Copmte Rendue de la Academie des Sciences, Paris 290, 179-182.

Marúnez Catalán, J.R., 1983. Deformación heterogénea en los macizos graníticos de Sarria y Santa Eulalia de Pena (provincia de Lugo). Stvdia Geologica Salmanicensia 18, 39-63.

Marúnez Catalán, J.R., 1985. Estratigrafía y estuctura del domo de Lugo (Sector Oeste de la zona Asturoccidental-leonesa). Corpus Geologicum Gallaeciae, $2^{\mathrm{a}}$ Serie, vol. 2

Manúnez Catalán, J.R., Pérez Estaún, A., Bastida, F., Pulgar, J.A., Marcos, A., 1990. West Asturian-Leonese Zone. Stucture. In: Dallmeyer, R.D., Marínez García, E. (Eds.), Pre-Mesozoic Geology of Iberia, SpringerVerlag, Berlin, pp. 103-114.

Matte, P., 1968. La swucture de la virgation hercynienne de Galice (Espagne). Revue de Géologie Al pine 44, 1-128.

Milnes, A.G., Wennberg, O.P., Skâr, Ø., Koestler, A.G., 1997. Con raction, extension and timing in the South Nonwegian Caledonides: the Sognefjord mansect. In: Burg, J.P., Ford, M. (Eds.), Orogeny Through Time. Geological Society Special Publication 121, pp. 123-148.

Miyashiro, A., 1961. Evolution of metamorphic belts. Journal of Petrology 2, 277-311

Molnar, P., Lyon-Caen, H., 1988. Some simple physical aspects of the support, swucture, and evolution of mountain belts. Geological Society of America Special Paper 218, 179-207.

Morley, C.K., 1988. Out-of-sequence thrusts. Tectonics 7, 539-561.

Mueller, K., Talling, P., 1997. Geomorphic evidence for tear faults accommodating lateral propagation of an active fault-bend fold, Wheeler Ridge, Califomia. Journal of Sructural Geology 19, 397-411.

Pérez-Estaún, A., 1978. Es rratigrafía y estructura de la rama Sur dela Zona Asturoccidental-Leonesa. Memorias del Instituto Geológico y Minero de España 92, 1-151.

Pérez-Estaún, A., Bastida, F., Alonso, J.L., Marquínez, J., Aller, J., Alvarez-Marrón, J., Marcos, A., Pulgar, J.A., 1988. A thin-skinned tectonics model for an arcuate fold and thrust belt: the Cantabrian Zone (Variscan Ibero-Amorican Arc). Tectonics 7, 517-537.

Pérez-Estaún, A., Marínez Catalán, J.R., Bastida, F., 1991. Crustal thickenning and deformation sequence in the footwall to the suture of the Variscan Belt of northwest Spain. Tectonophysics 191, 243-253.

Pérez-Estaún, A., Pulgar, J.A., Banda, E., Alvarez-Marrón, J., ESCI-N Research Group, 1994. Crustal structure of the external Variscides in NW Spain from deep seismic reflection profiling. Tectonophysics 232, 91-118

Pira, P., Burg, J.P., Schulmann, K., Ledru, P., 1994. Late orogenic extension in the Bohemian Massif: petros uctural evidence in the Hinsko region. Geodinamica Acta 7, 15-30.

Platt, J.P., 1984. Secondary cleavages in ductle shear zones. Journal of Swuctural Geology 6, 439-442.

Platt, J.P., 1986. Dynamics of orogenic wedges and the uplift of highpressure metamorphic rocks. Geological Society of America Bulletin 97, 1037-1053.

Platt, J.P., 1993. Exhumation of high-pressure rocks: a review of concepts and processes. Terra Nova 5, 119-133. 
Platt, J.P., Vissers, R.L.M., 1989. Extensional collapse of thickened continental lithosphere: a working hypothesis for the Alboran Sea and Gibraltar arc. Geology 17, 540-543.

Reche, J., Marúnez, F.J., Arboleya, M.L., Dietsch, C., Briggs, W.D., 1998. Evolution of a kyanite-bearing belt within a HT-LP orogen: the case of NW Variscan Iberia. Journal of Metamorphic Geology 16, 379-394.

Sandiford, M., 1989. Horizontal structures in granulite terrains: a record of mountain building or mountain collapse? Geology 17, 449-452.

Schmid, S.M., Casey, M., 1986. Complete fabric analysis of some commonly observed quartz c-axis patterns. Mineral and rock deformation. Laboratory Studies-The Paterson Volume. Geophysical Monograph 36, American Geophysical Union, pp. 263-286.

Shen, F., Royden, L.H., Burchfield, B.C., 2001. Large-scale crustal defornation of the Tibetan Plateau. Journal of Geophysical Research 106, 6793-6816.

Thompson, A.B., England, P.C., 1984. Pressure-temperature-time paths of regional metamorphism, II. Their inference and interpretation using mineral assemblages in metamorphic rocks. Journal of Petrology 25, 929-955.

Van Den Driessche, J., Bnm, J.P., 1991-1992. Tectonic evolution of the
Montagne Noire (french Massif Central): a model of extensional gneiss dome. Geodinamica Acta 5, 85-99.

Vanderhaeghe, O., Burg, J.P., Teyssier, C., 1999. Exhumation of migmatites in two collapsed orogens: Canadian Cordillera and French Variscides. In: Ring, U., Brandon, M.T., Lister, G.S., Willett, S.D. (Eds.), Exhumation Processes: Normal Fauling, Ductile Flow and Erosion. Geological Society Special Publication 154, pp. 181-2 4.

Wheeler, J., Butler, R.W.H., 1994. Criteria for identifying stuctures related to crustal extension in orogens. Journal of Structural Geology 16, $1023-1027$.

Wibberley, C.A.J., 1997. Three-dimensional geomery, strain rates and basement deformation mechanisms of thrust-bend folding. Journal of Swuctural Geology 19, 535-550

Wilson, C.J.L., 1973. The prograde microfabric in a defonned quartzite sequence, Mount Isa, Auswalia. Tectonophysics 19, 39-81.

Yin, A., Kelty, T.K., 1991. Development of normal faults during emplacement of a thrust sheet: an example from the Lewis allochthon, Glacier National Park, Montana (USA). Journal of Smuctural Geology $13,37-47$. 